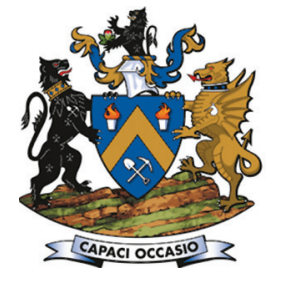

Affiliation:

${ }^{1}$ Minerals Resources and Reserves, University of the Witwatersrand, Johannesburg. South Africa.

2 Business Development, Buenaventura Mining, Lima, Peru.

Correspondence to:

A. Nieto

Email:

antonio.nieto@gmail.com

Dates:

Received: 9 Apr. 2019

Revised: 31 Jan. 2020

Accepted: 7 Aug. 2020

Published: July 2020

How to cite:

A. Nieto and Medina, J.F. Development of a socio-economic strategic risk index as an aid for the feasibility assessment of mining projects and operations. The Southern African Institute of Mining and Metallurgy

DOI ID:

http://dx.doi.org/10.17159/24119717/711/2020

ORCiD ID:

A. Nieto

https://orchid.org/0000-0003 1695-6501

\section{Development of a socio-economic strategic risk index as an aid for the feasibility assessment of mining projects and operations}

\author{
A. Nieto ${ }^{1}$ and J.F. Medina ${ }^{2}$
}

\section{Synopsis}

The uncertainty caused by social conflicts reflects serious problems of governance, which can have severe economic consequences. Currently, mining companies worldwide tend to adopt reactive approaches towards social demands, which can easily evolve into social conflicts. The risk of social disruption could be minimized if companies take preventive actions, adopting sound social management policies. To do so, the social and environmental conditions of each particular operation need considerable evaluation and planning. Positive results would translate into secure investments and social peace, ultimately resulting in positive economic development in the region. Social conflicts in the mining industry have caused millions of dollars in losses due to production delays, redesign of projects, damage to equipment, and even the closing of operations. Additionally, prior to the development of any mining project, companies are responsible for obtaining approval from local communities (the social license to operate - SLTO). In order to secure a new SLTO, companies often use corporate social responsibility (CSR) strategies to deal with existing and potential social conflict situations. However, current CSR strategies are limited by the inability to quantify risk. There is therefore a need for a socio-economic risk index that considers quantifiable factors that can be used to effectively manage and mitigate social risk. In the present study, competition for the use of water, land, and labour were identified as the major causes of social conflict around mining operations. Competition can be subdivided by consumption of strategic resources and by the level of interaction between mining operations and local communities. Index value results have been analysed and compared using real case scenarios from eight gold mining operations around the world. This study is intended to present a new alternative to measure socio-economic risk in order to prevent feasibility and financial failure of future mining investments.

\section{Keywords}

socio-economic risk, social license to operate, resource competition, risk quantification.

\title{
Introduction
}

The economic and market conditions in the minerals and mining industry in the last two decades provoked the proliferation of social conflicts in mining districts (International Council on Mining and Metals, 2015). Social conflict in a business such as mining, which operates in rural areas, and sometimes even close to urban centres, where interaction with communities occurs constantly, has the potential to affect the economics of the operation. A survey of 19 junior gold mining companies concluded that two-thirds of the market capitalization could be attributed to an organization's effective social policies, while only one-third was the result of the gold value underground (Daniel, 2014). Another economic consequence of social conflicts around mining projects is the loss of production due to delays. A report presented by Franks et al. (2014) indicates that a world-class mining organization with a project capital of US\$3-6 billion suffered losses of approximately US\$20 million per week in terms of NPV due to production delays related to social conflict. For instance, a Latin American mine faced a 9-month delay which cost US $\$ 100$ million in stoppages. In another case, a community conflict resulted in a shutdown of the electricity supply lines, costing the company US\$750 000 a day (OCMAL, 2015).

Social conflicts also have an effect at the macro-economic level. In one study, the Economic Peruvian Institute (IPE) estimated that US\$21.5 billion in investment was lost since 2011 as a result of social or political conflicts. According to the IPE, these conflicts adversely impacted the revenues received by the government in corporate taxes and the GDP growth of the country (El Economista, 2015).

It is clear that social unrest can cause significant losses to a mining operation. Therefore, and taking into account the fact that social conflicts are not a new issue for mining, several social strategies 


\section{Development of a socio-economic strategic risk index as an aid for the feasibility assessment}

have been implemented for the reduction of conflicts with local communities. The first one, the social license to operate (SLTO), was proposed in 1997 by Jim Cooney, then Director of International Public Affairs at Placer Dome. It was born as the result of the social conflicts experienced by the mining industry during the 1990s. The conflicts were primarily due to environmental incidents that diminished the reputation of mining companies (Smith and Richards, 2015). The SLTO includes the local communities affected by a mining project in the decisionmaking process.

According to Thomson and Boutilier (2011), there are three major criteria that a company must meet to achieve the highest level of social license: legitimacy, credibility, and trust. Legitimacy is the result of communication with communities to inform them about the status and history of the past projects developed by the company (Smith and Richards, 2015). In addition, to establish legitimacy, the participation of all the community members is required in planning and decision-making. Credibility is the quality of trustworthiness, and therefore depends on transparency and consistency in decision-making (Smith and Richards, 2015). Trust, the final criterion, is the degree to which local communities support the company's actions. The SLTO is therefore seen as a tool used to reduce the corporate risk involved in mining projects (Thomson and Boutilier, 2011).

Another approach used for the management of social conflicts that is widely implemented in mining is the corporate social responsibility (CSR) rating. CSR was born in the 1960s when the world began to ask about the role that corporations must play in society and the different levels of responsibility they should embrace. According to Davis (1975), social responsibility involves the protection and improvement of society's interests to achieve harmony between business actions and social systems. CSR is a well-established planning tool for the management of stakeholders' expectations regarding social responsibility of businesses and the execution of 'social investment' plans (International Institute for Sustainable Development, 2007). It also takes into consideration the social, environmental, and health concerns of the stakeholders. However, even with the assistance provided by SLTO and CSR, social conflict still represents a major issue for mining operations. Thus, it can be deduced that SLTO and CSR strategies have not been effective solutions to conflicts with local communities. They are missing an important factor for more effective risk management: how to measure social risk (Bekefi and Epstein, 2006).

\section{Objective and approach}

The complexity of social risk and its impact on mining operations worldwide depends primarily on the type of mine and the geographic location. As previously mentioned, the mining industry tends to interact with communities at both the urban and rural levels, and therefore the cost associated with this type of risk increases significantly. To counteract this problem, mining companies require a new approach to measure social risk in their technical and economic decisions. The social profile of every community for social risk analysis may include the mapping of current economic factors such as the unemployment rate, and key population variables to design plans that could reduce social risk. This kind of strategic risk planning is meant to secure mining investments and mine development. Since this challenge still remains for mining companies, the objective of this paper is to present a new approach to measure social risk.
There are two different ways to measure risk: qualitative and quantitative approaches (Bekefi and Epstein, 2006). Whereas a qualitative approach produces data in the form of descriptive formal text, the quantitative approach states data numerically (Garbarino. and Holland, 2009). This paper presents a new approach to measure social risk in mining operations that combines qualitative and quantitative factors based on clear, quantifiable, and traceable metrics.

The quantitative approach is based on four different resources that have been identified as strategic in the development of mining projects: water, land, energy, and labour. However, based on the International Council on Mining and Metals (ICMM) reports (International Council on Mining and Metals, 2012, 2015), competition for all the mentioned resources, with the exception of energy, has been the major cause of social conflicts between mining companies and communities.

A study of the social conflicts associated with the competition for the three conflict-related strategic resources reveals there are two major competitors that mining companies may encounter: local communities and local businesses. The social risk associated with a mine is therefore the result of competition for strategic resources between a mine and the two local parties.

Competition for strategic resources is quantified using five parameters that measure the consumption of water, land, and labour. In addition, two parameters that measure the level of interaction between mines and local communities are included. The parameters are integrated in a mathematical expression or index that provides a final quantification of social risk. The value depends on the level of consumption and the probability of social conflicts associated with each strategic resource. Figure 1 shows the structure of the social risk index.

Competition is quantified by the necessity of access to these three resources by (1) the mining project, (2) community population, and (3) local businesses. The level of the interaction between the mine and local communities is quantified by (4) the geographical distance between them, and (5) the development stage of the mining operation. For all the five variables, a value between 1 and 10, and a weight (percentage) that represents the influence of each parameter in social risk, is assigned. Then, the use of a mathematical model provides final values (score) that helps reveal an estimated measurement of the social risks per strategic resource. Finally, the score obtained for each resource is adjusted according to the results of a previously developed survey that revealed the degree of importance of each resource compared

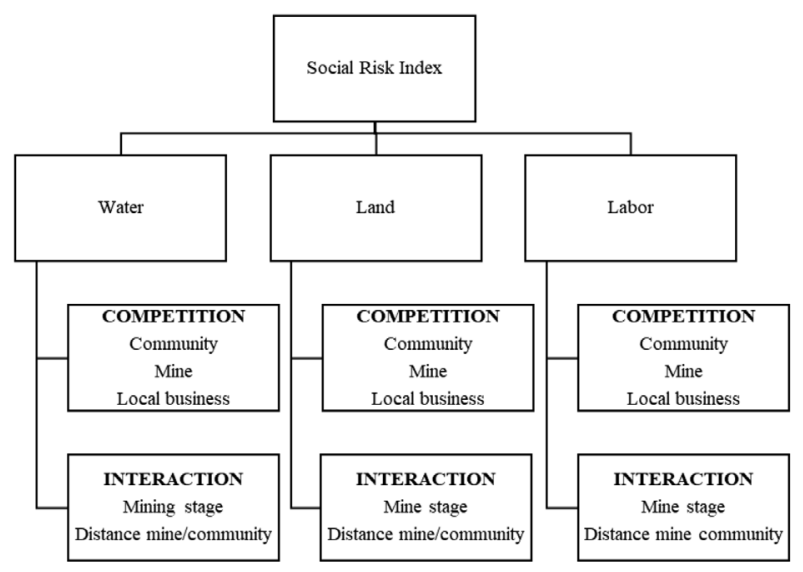

Figure 1-The social risk index model 


\section{Development of a socio-economic strategic risk index as an aid for the feasibility assessment}

to the others. The final value is then considered the social risk index. This new approach presented for measuring social risk in mining operations is based on a combination of the qualitative and quantitative research methodologies.

The index was validated through eight case studies of mining projects located in Argentina, Brazil, Bulgaria, Colombia, and Kyrgyzstan. The eight case studies were selected based on two parameters: the community-mine profile and whether or not they experienced social conflicts that prevented the development of the mine. The results suggest that, based on the information regarding competition for strategic resources and the interaction between actors, the index has the ability to identify levels of risk associated with social conflicts. In the particular case of gold mining, the four projects that experienced serious social conflicts were evaluated with a social risk index above 5 , while the projects with scores below 5 did not experience major social conflicts.

\section{Social risk in mining operations}

Mining is probably one of the most challenging industries as a result of the technical complexity involved in mining projects and the capital investment required. Firstly, opening a mine for production is a long process that can take between 5 and 15 years, and up to US\$500 million in investment (Hartman, 1987). It requires permits from local and national governments to utilize natural resources such as water and land, and the approval to operate by local communities. In addition, mineral deposits are located in regions that may or may not have sufficient political and social stability to guarantee a healthy and normal development of the mining operation. Furthermore, mining is a commodity-based business. Therefore, the profits created by mining depend on international prices that fluctuate as a consequence of supply and demand, as well as economic and political conditions of the international markets.

Another risk factor in mining, which has risen significantly over the last two decades, is social risk (International Council on Mining and Metals, 2012). Social risk, from a business perspective, occurs when companies fail to gain the SLTO from communities located close to the mines. The negative response and rejection that communities display towards mining projects can create social conflicts that may escalate to demonstrations and property damage. In addition, social conflicts have the potential to cause a mine to lose productivity and opportunity, and damage a company's reputation (International Council on Mining and Metals, 2012). This section explains the concept and components of the social risk associated with a mining operation.

\section{Social risk and strategic risk}

Risk is typically defined as the effect of uncertainty on objectives, or as the combination of the probability and consequence of an event (or outcome). This leads to the following simple and widely used mathematical expression for risk:

\section{Risk=Probability $\times$ Consequence}

At the corporate level, risks usually fall into two categories: strategic and operational. Strategic risks affect the business operation in the long run. They measure the current business environment in order to prepare action plans to meet shortand long-term needs (Summers, 2000). For example, water scarcity is considered a strategic risk that mining companies are facing today. Issues regarding water access at a mine or mineral processing facility impact the production capacity.
Operational risks, on the other hand, are typically preventable, and occur as a result of inadequate or failed systems, people, and external events. Health and safety hazards are examples of operational risks in mining. As a result of the direct impact on mineral production and business profitability, social risks must be approached as strategic risks. However, mining companies tend to consider social risks as operational, or minor, risks that can be mitigated through corporate social responsibility (CSR) strategies. Although CSR is a valid risk management tool, it does not provide companies with the inputs required to include social risk in strategic mining plans.

\section{Mining feasibility and social risk}

Pre-feasibility and feasibility studies in mining are complex, extensive reports that study the possibility of developing the mineral deposit into a producing mine and are based on economic potential (mineral reserves) and scientific and technical conditions such as the infrastructure required to build the mine (Hartman, 1992). Pre-feasibility and feasibility studies are defined in the CRIRSCO template and the standards and codes of all the major mining countries. However, in many cases social risk is not included as a major topic; instead, feasibility reports present a brief description of the socio-economic conditions of the mining zone. Because of the non-consideration of social risks as a strategic risk when starting new mining projects, mining companies have been forced to cancel or abandon ongoing projects, resulting in massive capex losses (Davis and Franks, 2014). Thus, mining feasibility studies would benefit from incorporating quantifiable social risk into their evaluations to better understand investment and economic risk when considering a new mining operation. The following sections explain the main components of social risks.

\section{Ernst and Young - Mining Report}

Ernst and Young (EY) is considered a leader in assurance, tax, and advisory services. The company provides consulting services for the mining and metals industry, including financial evaluations, information on tax regulations, capital markets advisory, accounting support, sustainability strategies, valuation, and business models etc. In addition, EY prepares reports on business risks in the mining and metals industry. EY's eighth annual report analyses and ranking the top strategic business risks for companies in the sector. The report is the result of discussions with leading mining companies and the analysis of the operating environment for the companies in the field.

Although EY's report presents a general and broad list of business risks, it helps to identify factors associated with the production mining cycle. Table I presents EY's ranking for business risks in mining and metals 2015/2016. The factors in bold are associated with technical considerations of the mining process.

The reports presented above are used as a guide to identify major strategic risk factors experienced by mining companies as seen in Table II.

\section{Mining and social risk}

Social conflicts in mining can be explained as the result of the changes mining produces in the social, economic, and environmental systems of the communities located close to the mining projects. These changes and the associated social risks evolve through the different stages required for the development of a mine, typically starting with a low risk level during 


\section{Development of a socio-economic strategic risk index as an aid for the feasibility assessment}

\section{Table I}

\section{Strategic business risks in mining and metals (EY, 2015)}

1. Switch to growth

2. Productivity improvement

3. Capital access

4. Resource nationalism

5. Social license to operate

6. Price and currency volatility

7. Capital projects

8. Access to energy

9. Cybersecurity

10. Innovation
11. Balancing talent requirements

12. Infrastructure access

13. Access to water

14. Threat of substitutes

15. Stranded assets

16. Pipeline shrinkage

17. Fraud and corruption

18. Sharing the benefits

19. Climate change

20. Geopolitical uncertainty

\section{Table II}

\section{Strategic risk factors in mining}

\begin{tabular}{|l|l|}
\hline \multicolumn{2}{|c|}{ Risk factor } \\
\hline Access to water & Technical \\
Acquisition and negotiation of land & Technical \\
Access to energy & Technical \\
Access to medium-skill/unskilled labour & Technical \\
Access to infrastructure & Technical \\
Biodiversity & Technical \\
Goods and services (supply capacity of local communities) & Technical \\
Political stability of the mining region & Strategic \\
Mining laws and regulations of the region & Strategic \\
\hline
\end{tabular}

prospecting and increasing significantly during exploration, as indicated by the dotted line in Figure 2. Typically, mining involves a sequence of five major stages: prospecting, exploration, development, mining/extraction, and closure/reclamation, as seen in Figure 2

\section{Social conflicts and strategic resources}

Social risks and conflicts in mining are the result of interaction between mines and communities at different levels and stages, as discussed in the previous section. Planning for the prevention of social conflicts is not an easy task, since community-mine interactions are complex and multidimensional on the social, economic, and cultural levels. This paper presents a general approach to study social conflicts that may be applied to different community-mine profiles. The approach presented explains social conflicts as the result of the competition with communities, created by mining projects, for three strategic resources identified in Table II: water, land, and labour.

There are three key strategic resources required for mineral production that has been identified in this study, which are also essential elements for the development of both communities and mines and which are always present during the five mining stages shown in Figure 2: (1) water, (2) land, and (3) labour. Water is used in the extraction phase and for mineral processing. Water is also essential for local communities for human consumption and farming. Land provides access and space for infrastructure and is the main access to the underground ore. Labour is strategic as well, since it is a crucial resource to operate the mine, and one that may face competition from local businesses.

\section{Social risk of water use}

Water is an essential resource for sustaining life, and access to it is considered a human right (United Nations, 2010). Water is

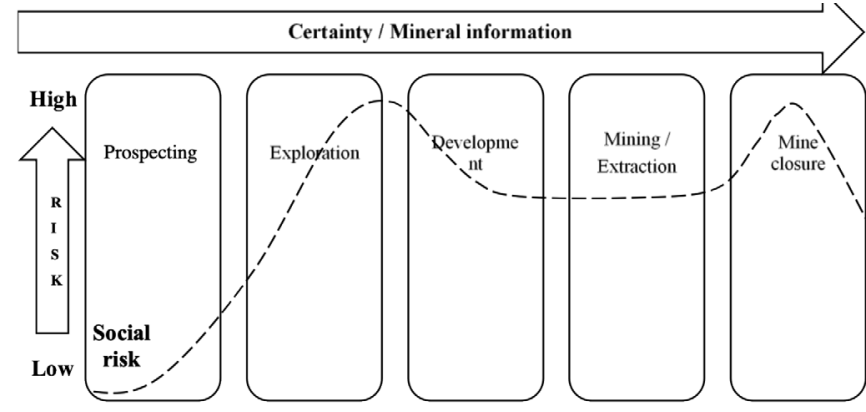

Figure 2-Social risk profile over the mining project life-cycle

used in all the stages of mineral production, and today, as a result of shortages, water is considered a major cost for mining (AMEC Earth \& Environment UK Ltd, 2014). Water consumption in a mine depends on the metal content and type of mineral extracted. In gold mining it is typically used in the following activities:

- Transportation of ore and waste in slurries and suspensions

- Separation of minerals through chemical processing (heap leaching)

> Physical separation of material, such as centrifugal separation

> Cooling systems around power generation

> Dust control in mineral processing and around conveyors and roads. Dust control in underground mines is a major consumer of water, as is rock drilling

> Domestic consumption in camps and other facilities.

Although there are other industries that consume more water than mining, mining is usually associated with negative impacts and water pollution (International Finance Corporation, 2014). This is the result of a legacy of water-related environmental incidents. Water incidents in mining have occurred as a result of spills or the infiltration of polluted water into surface and underground water bodies. Pollution of water occurs as a result of the nature of the ore, the extraction, and the processing method used. Additionally, for the processing of minerals, mining uses chemical reagents such as cyanide and sulphuric acid, and water pollution may occur due to spillage of waste from mineral processing (Kihlstedt, 1972)). Usually, the use of water in mining generates a negative perception among local communities, which believe that mines will affect the quantity and quality of water (International Council on Mining and Metals, 2014), impacting local businesses such as agriculture.

\section{Social risk of land use}

Access to land and the in-situ mineralization is a key factor in any mining operation for starting exploration activities, building infrastructure and facilities such as camps, offices, and the processing plant, for installing electricity and water infrastructure, building tailing facilities, and several other crucial aspects of a mining operation that require land ownership and mining rights to extract the ore from below the surface.

Land use and acquisition is another serious aspect that involves social risk. The main problems of this matter are the legal aspects associated with land distribution and ownership. In developing countries, rural land was redistributed among farmers through agrarian reforms that occurred during the 1960 s and 1970s for the purpose of promoting agriculture. However, the 


\section{Development of a socio-economic strategic risk index as an aid for the feasibility assessment}

lack of expertise of the new landlords provoked a crisis in the local production of food (e.g. Peru and Zambia). Another effect of these reforms is the ambiguity created in the ownership of land. In countries such as Peru, for instance, vast areas are abandoned due to migration of people to urban areas. The problem arises when mining companies discover a new potential area and start asking who owns the land, so that they might proceed with either the leasing or buying process (e.g. Papua New Guinea). The issue could be even worse if after a land-use agreement is reached, a third party claims to have rights on the properties already negotiated (Hilson, 2002).

Even though mining usually occurs in uninhabitable and remote locations, sometimes the deposits lie close to or even beneath towns or cities. This requires the relocation of people, a complex process that severely impacts the economic and social identity of communities.

Reclamation and mine closure are another issue associated with land management in mining. Concerns about the disturbance of the land after mining and its future use in farming and agricultural activities are common. Additionally, people often blame the mining operation for the low production capacity of their crops, stating that mining affects the soil of the surrounding properties

\section{Social risk associated with labour}

Communities always have high expectations about the economic benefits they might derive from mines. Employment at the mine is one of the major expectations. Therefore, mining companies generally try to employ as much local labour as possible. The failure of a company to provide locals with jobs is considered a factor for social risk (International Council on Mining and Metals, 2014). On the other hand, if the demand for workers is too high, there might be competition for workers between local industries and mining. In addition, the fluctuations in the mining sector produced by market conditions have an impact on the availability and quality of labour. During the supercycles, when commodity prices are high, labour scarcity is a risk factor. On the contrary, low prices force the mining companies to implement a series of cost-cutting measures, usually associated with reductions in the workforce. These changes in labour requirements produce tension between mining companies and local communities.

\section{Strategic resources and social conflicts}

This section presents social conflicts in mining. The social conflicts identified in this paper are associated with strategic resources. The objective of this comparison is to evaluate how competition for strategic resources can explain social conflicts

The report was prepared by the International Council on Mining and Metals (ICMM), a private organization composed of 22 mining companies and 34 national and regional mining associations created with the purpose of addressing sustainable development challenges experienced by the mining industry. The report is based on information from 11 publicly available sources, and was developed to identify the number of companycommunity conflicts that occurred from 2002 to 2013. The research found 'a progressive increase in the number of reported incidents between 2002 and 2013. This occurred over a period of significant investment in the mining and metals sector' (ICMM, 2015). As seen in Figure 3, the research identified 15 causes of conflict, led primarily by environmental, economic, and public health and safety concerns. The ICMM report defines environmental conflict as the perception of negative impact on air quality, water pollution, noise, and government capacity to monitor and regulate. Economic conflict is defined as the perception of inequitable distribution of benefits across socioeconomic groups, and insufficient impact on local employment and business. Health and safety issues are associated with health and safety failures experienced by communities. The conflicts were found in 30 different countries. Figure 3 shows the conflict mapping presented in the ICMM's research.

Table III shows the correlation of social conflict versus the three main strategic risk resources: water, land, and labour, clearly indicating that social conflict is significantly influenced by competition for these resources. The 15 social conflicts mentioned in the table and their relationship with strategic resources are described below.

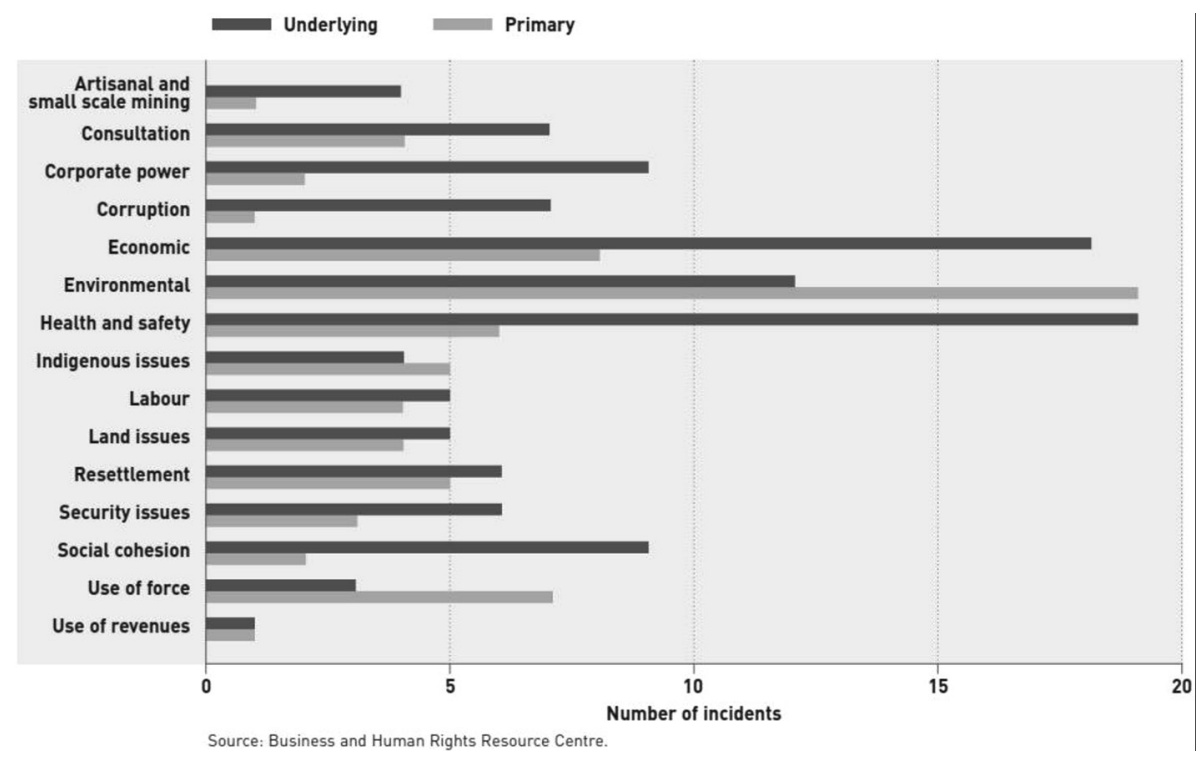

Figure 3-Most common conflicts in mining (ICMM, 2015) 


\section{Development of a socio-economic strategic risk index as an aid for the feasibility assessment}

\section{Table III}

Social conflicts and strategic resources (ICMM, 2015)

\begin{tabular}{|c|c|c|c|c|}
\hline \multirow[t]{2}{*}{ Social conflict } & \multicolumn{3}{|c|}{ Strategic resources } & \multirow[t]{2}{*}{ Causes for conflict } \\
\hline & Water & Land & Labor & \\
\hline $\begin{array}{l}\text { Artisanal and small scale mining } \\
\text { Consultation } \\
\text { Corporate power } \\
\text { Corruption }\end{array}$ & & $x$ & $x$ & Competition for land and territory \\
\hline Economic & $\mathrm{x}$ & $x$ & $\mathrm{x}$ & Competition for resources to make profit, inequitable distribution of benefits \\
\hline Environmental & $\mathrm{x}$ & $x$ & & Pollution of resources \\
\hline Health and safety & $x$ & & & Pollution of resources \\
\hline Indigenous issues & $x$ & $x$ & $x$ & Competition for land and territory \\
\hline Labor & & & $x$ & Access to employment \\
\hline Land issues & & $x$ & & Access to land for farming and other activities \\
\hline Resettlement & & $x$ & & Unfair resettlement \\
\hline Security issues & & & & \\
\hline Social cohesion & $x$ & $x$ & $x$ & Distribution of social order through migration \\
\hline Use of force & & & & \\
\hline Use of revenues & & $\mathrm{x}$ & $x$ & Conflict between different groups over distribution of revenues \\
\hline
\end{tabular}

\section{Social risk index and strategic resources}

An index is defined as a composite of variables, or a method of measuring a concept using more than one data item. It is the result of an accumulation of scores from individual items that define the concept. Therefore, an index is a single value that captures the information from the variables and scores that describe the concept. It is typically expressed as:

$$
\text { Index }=a_{1} X_{1}+a_{2} X_{2}+a_{3} X_{3}+\cdots+a_{n} X_{n}
$$

The term $a_{i}$ is the weight of the $X_{i}$ variables that describe the index or concept. The concept that this study aims to approach and measure is the social risk experienced by mining companies. As discussed in the previous section, social risk as defined in this paper is the result of the competition between mines and communities for three strategic resources: water, land, and labour. Competition for each strategic resource provokes social conflict. For instance, the consumption of water for mining is associated with health problems by communities. Therefore, there is a risk associated with each strategic resource. Applying the description above, the social risk index in mining can be defined as:

Social risk index $=a_{1} \times$ Social risk of water $+a_{2} \times$ Social risk of land $+a_{3} \times$ Social risk of labour

The social risks associated with water, land, and labour are in fact separate indices, since they are single values that depend on a set of parameters and each parameter has a different weight or incidence in the final score per risk.

\section{Parameters for the measurement of competition}

The parameters used to describe the social risks for water, land, and labour are measurements of two conditions typically associated with conflicts: the level of competition for the strategic resources and the level of the interaction between mines and communities. These are the parameters that measure the consumption of strategic resources. During mine-community interactions, there are three major competitors for strategic resources: local communities, local businesses, and the mine. This study makes the assumption that the following parameters provide an approximation for the water, land, and labour consumed by the three competitors.

\section{Population size (water and land consumption): This} parameter represents the size of the population that will be directly affected by the mine. The water consumption rate of a community is directly associated with the number of people, since everybody needs water for living and daily activities. Similarly, the area of land use by communities is associated with the size of the population. Therefore, competition for land and water is related to the size of the population of the communities located close to the mines.

- Percentage of population that depends economically on water/land: Today, mining occurs in remote rural regions where competition with other economic activities for natural resources such as land and water could create social conflicts. Therefore, people who depend economically on activities such as agriculture, for instance, are seen as competitors for strategic resources. Social conflicts with this group occur when they feel they are being unfairly treated, inadequately compensated, and the cost/benefit relationship produced by the mine is unbalanced for their business (Wagner, 2010). Another consequence of the opening of a mine is the migration of labour from local business to the mine. People prefer to work in mines, as they may have access to better salaries and benefits (Meridian Gold, 2006). This parameter is therefore included in the social risk of water, land, and labour, since there is direct competition between the local businesses and mines for the strategic resources. This parameter is typically measured as a percentage of the total population (e.g. the percentage of the population whose economic activity is agriculture).

- Number of local people who can be employed at the mine: Although mining creates new jobs in local communities, a new mining operation in a local community could create tension among the population due to expectations of the community to have access to the economic benefits brought by the mine. The number of new employment positions for locals created by a mine was estimated as $60 \%$ of the total labour requirement. This factor represents the typical number for unskilled and semi-skilled workers required by a mine. Therefore, the number of locals who can work 


\section{Development of a socio-economic strategic risk index as an aid for the feasibility assessment}

at the mine is calculated as the ratio of unemployment to unskilled or semi-skilled workers required in the mine. This parameter is used in the computation of the social risk associated with labour.

> Water used for mining: According to the ICMM report, water is the number one reason for social conflicts in mining. Additionally, the World Bank Group's Compliance Advisor Ombudsman (CAO), an agency that responds to complaints from project-affected communities, finds that $68 \%$ of mining-related complaints include water issues (International Finance Corporation, 2014). This parameter only takes into account water consumed for mining and mineral processing and does not account for the discharge of water from the mining process. This parameter is usually measured as the number of tons of ore processed per day per cubic metre of water consumed. Therefore, the water consumption of a mine provides an idea of the size of the operation.

> Land used for mining: Land is another strategic resource that involves social risk. Mining uses land in all five stages of the life-cycle and this requires close interaction with local communities. Land used for mining is defined for this study as the extent of land used for exploration and mining activities.

Social risk depends as well on the level of the interactions between mines and communities. As was discussed, social risks depend on the stage of the operation. In addition, the distance between these two actors is assumed as a risk factor.

> Mining stage: Conflicts are associated with the current operational stage of the mine. As seen in Figure 2, after the prospecting stage, social risk increases significantly as the project moves into exploration and eventually into the development, production, and closure stages.

- Distance between communities and the mine: In this project, the distance between communities and mines is considered a factor that influences the occurrence of social conflicts between the actors. Therefore, larger distances imply lower risk than short distances. This assumption was made based on the case studies analysed in the following section

\section{Social risk associated with water use}

The calculation of the social risk associated with water is based on the following expression

Social risk for water $=w_{1} \times$ Water used for mining $+w_{2} \times$ Mining stage $+w_{3} \times$ People who depend economically on water $+w_{4} \times$ Distance $+w_{5} \times$ Population

The weights for each parameter were estimated based on how well they can explain the occurrence of social conflicts. Therefore, the use of water for mining has the highest weight (0.4) since this is the major factor for social conflicts (it is perceived by communities with negative impacts on health and the environment). The mining stage is also assigned with a weighting factor since is major factor as explained previously. Social conflicts typically occur during the feasibility and prefeasibility stages, as these involve permitting and social consultation. This implies that the mining stage may be seen as a measure for the interaction between mines and communities. For instance, if a mine has been in production without interruption for more than five years, it may be surmised that communication between mine and community is in a healthy condition.
Therefore, the mining stage provides valuable information about the occurrence of social conflicts, and was given a weight of 0.3. In addition, water and the mining stage are the two most significant parameters, since there is evidence from the literature that these two are major reasons for social conflicts (Davis and Franks, 2014). The number of people whose economic activity depends on water was weighted 0.15 . This is lower than the weight for the mining stage, since this represents the risk from a specific group in the community, whereas the social risk of the mining stage and water involves the entire population. However, this parameter explains the social conflicts that may occur due to competition for strategic resources with the local industries, which in some cases involve more than $60 \%$ of the total population. The weight for the distance between communities and mines is 0.1 . This parameter provides information on the level of interaction between communities and the mine which, to some extent, may explain conflicts. Therefore, social conflicts are most likely to occur when the interaction is high, or when the distance between the actors is short. However, this parameter requires more information in order to define a social conflict. Finally, population size was assigned a weight of 0.05 . Although this is an important parameter, the information provided by the size of the population needs to be considered together with other relevant factors, such as the water used by the mine, in order to explain the occurrence of social conflict.

Hence, the final equation used to calculate the social risk associated with water is:

Social risk of water $=(0.4) \times$ Water used for mining $+(0.3) \times$ Mining stage $+(0.15) \times$ People who depend economically on water $+(0.1) \times$ Distance + (0.05) x Population

\section{Social risk associated with land use}

The calculation of the social risk associated with land is based on the following equation:

Social risk for land $=\mathrm{l}_{1} \times$ Land used for mining $+\mathrm{l}_{2} \times$ Mining stage $+1_{3} \times$ People who depend economically on land $+1_{4} \times$ Distance $+1_{5} \times$ Population

The weights for each parameter were estimated using the same logic as used for water. In fact the values assigned to the mining stage and distance are the same for both land and water. The use of land for mining is a major issue (weight 0.3), since it implies socioeconomic changes provoked by relocation and migration of people. The population size (0.1) and the population who economically depend on land (0.2) are more representative factors for the social risk of land than that of water. This is explained by the fact that land is a resource owned by people or communities. Therefore, they are more involved in the issues or conflicts associated with land.

\section{Table IV}

Weights used to calculate the social risk of water

\begin{tabular}{|c|c|}
\hline Parameter & Weight \\
\hline 1. Water used for mining & $w_{1} \quad 0.4$ \\
\hline 2. Mining progress stage & 0.3 \\
\hline 3. \% of population that depends economically on water & 0.15 \\
\hline 4. Distance between communities and the mine & $\begin{array}{ll}w_{4} & 0.1\end{array}$ \\
\hline 5. Population size & $w_{5} \quad 0.05$ \\
\hline
\end{tabular}




\section{Development of a socio-economic strategic risk index as an aid for the feasibility assessment}

\section{Table V}

\section{Weights used to calculate the social risk of land}

\begin{tabular}{|l|cc|}
\hline Parameter & \multicolumn{3}{|c|}{ Weight } \\
\hline Land used for mining & $\mathrm{I}_{1}$ & 0.3 \\
Mining stage & $\mathrm{I}_{2}$ & 0.3 \\
Population that depend economically on land & $\mathrm{I}_{3}$ & 0.2 \\
Distance between communities and the mine & $\mathrm{I}_{4}$ & 0.1 \\
Population size & $\mathrm{I}_{5}$ & 0.1 \\
\hline
\end{tabular}

Hence, the final equation used to calculate the social risk associated with land is:

Social risk of land use $=(0.3) \times$ Land used for mining $+(0.3) \times$ Mining stage $+(0.2) \times$ People who depend economically on land $+(0.1) \times$ Distance $+(0.1) \times$ Population

\section{Social risk associated with labour}

The calculation of the social risk associated with labour is based on the following expression

Social risk for labour $=\mathrm{y}_{1} \times$ Unemployment /unskilled, mid-skilled people required $+\mathrm{y}_{2} \times$ Mining stage $+\mathrm{y}_{3} \times \%$ of population that depends economically on S.R

$+\mathrm{y}_{4} \times$ Distance $+\mathrm{y}_{5} \times$ Population

The parameter for unemployment / unskilled/mid-skilled people required by the mine has the highest weight, since this represents the number of local people who can be employed at the mine. This is critical, since employment is one of the most common demands from local communities. The mining stage is also an important cause for conflict, since availability of employment depends on this parameter. The migration of labour to the mines may cause disagreements with local businesses, since the new economic conditions created by mines are associated with inflation of the prices of labour, goods, and services (Davis and Franks, 2014). The weight for this parameter is 0.15 . As stated above, mines are often developed in remote areas where there are no local industries. Industries are drawn to areas of economic activity such as mines. Distance and size of the population are the parameter with the lowest weights. Although they are important since, to some extent, they represent expectations of employment (large communities imply a large demand for employment), they do not provide enough information for the definition of a social conflict.

Hence, the final equation used to calculate the social risk associated with water is:
Social risk of water $=(0.4) \times$ water used for mining + $(0.3) \times$ mining stage $+(0.15) \times$ people who depend economically on water $+(0.1) x$ distance $+(0.05) x$ population

\section{Risk parameter ranking}

To compute the value for the social risk associated with water, land, and labour, the score of each parameter is ranked from 1 to 10 . Therefore, the final value for the social risk of each strategic resource is also between 1 and 10. The rankings allow for the comparison of parameters among different mines. For instance, if mine $\mathrm{X}$ consumes more than $50000 \mathrm{~m}^{3}$ of water per day, and mine $Y$ only $5000 \mathrm{~m} 3 / \mathrm{d}$, the ranking for mine $\mathrm{X}$ will be higher than that for mine $Y$. In addition, the ranking system used assigns high ranks to high levels of social risk. Therefore, if a parameter is ranked 10 , this parameter is highly associated with risk. On the other hand, if the rank was 1, there is hardly any social risk involved with the parameter. In order to have a wide range of values to represent and rank several mining and community profiles, eight case studies were selected based on the mine size and mine-community distance. The information provided (per parameter) is organized in intervals. Then a rank (between 1 and 10) is assigned to each interval. The intervals were calculated using the mean of the values (per parameter) which was allotted the median rank of 5 . The range of the dataset was calculated and the ranks were distributed appropriately. This ranking system can be used for all types of mines and commodities. However, water is the only parameter that changes, since the amount of water required by a mine depends on the size and the commodity extracted (Yamana Gold, 2008). As mentioned before, the case studies are gold mines, so the ranks provided for water consumption are for gold mining. The ranking system based on the eight case studies is presented in Tables VII and VIII.

From Table VII, the water consumption of populations greater than 100000 is greater than $45000 \mathrm{~m} 3 / \mathrm{d}$, and distances

\section{Table VI}

\section{Weights used to calculate the social risk of labour}

\begin{tabular}{|l|rr|}
\hline Parameter & \multicolumn{3}{|c|}{ Weight } \\
\hline Unemployment / unskilled, mid-skilled people required & $y_{1}$ & 0.5 \\
Mining stage & $y_{2}$ & 0.2 \\
\% of population that depends economically on S.R & $y_{3}$ & 0.15 \\
Distance between communities and the mine & $y_{4}$ & 0.1 \\
Population size & $y_{5}$ & 0.05 \\
\hline
\end{tabular}

\section{Table VII}

\section{Ranking system for parameters}

\begin{tabular}{|c|c|c|c|c|c|c|c|}
\hline \multicolumn{2}{|c|}{ Population rank } & \multicolumn{2}{|c|}{ Use of water ( $\mathrm{m}^{3} /$ day) } & \multicolumn{2}{|c|}{ Mining stage } & \multicolumn{2}{|c|}{ Distance (km) } \\
\hline Risk & Interval & Risk & Interval & Risk & Interval & Risk & Interval \\
\hline 10 & $>100001$ & 10 & $>45001$ & 10 & Feasibility & 10 & $<3$ \\
\hline 9 & $90001-100000$ & 9 & $40001-45000$ & 9 & Prefeasibility & 9 & $4-5$ \\
\hline 8 & $80001-90000$ & 8 & $35001-40000$ & 8 & Exploration & 8 & $6-7$ \\
\hline 7 & $70001-80000$ & 7 & $30001-35000$ & 7 & Prospecting & 7 & $8-9$ \\
\hline 6 & $60,001-70,000$ & 6 & $25001-30000$ & 6 & Development & 6 & $10-11$ \\
\hline 5 & $50001-60000$ & 5 & $20001-25000$ & 5 & $>1$ year & 5 & $12-13$ \\
\hline 4 & $40001-50000$ & 4 & $15001-20000$ & 4 & $>5$ years & 4 & $15-14$ \\
\hline 3 & $30001-40000$ & 3 & $10001-15000$ & 3 & $>10$ years & 3 & $16-17$ \\
\hline 2 & $20001-30000$ & 2 & $5001-10000$ & 2 & $>15$ years & 2 & $18-19$ \\
\hline 1 & $<20000$ & 1 & $<5000$ & 1 & $>20$ years & 1 & $>20$ \\
\hline
\end{tabular}




\section{Development of a socio-economic strategic risk index as an aid for the feasibility assessment}

between mines and communities less than $3 \mathrm{~km}$ represent high levels of social risk. Similarly, feasibility is the most risky mining stage.

Table VIII indicates that if a mine uses more than 100000 ha of land, employs $5 \%$ or less of the local unemployed population, and the population that depends economically on water is greater than 45000 , a high social risk should be associated with these parameters. This methodology for ranking can be improved if information from more mines is included.

\section{Social risk index calculation}

With the weights and ranks for each parameter, the social risk associated with water, land, and labour can be calculated. Therefore, the only parameters that have not been calculated are the weights $a_{1}, a_{2}$, and $a_{3}$ for the estimation of the social risk index. They represent the strength and influence of each of the three components in the final index. To calculate the weights, a survey to measure the importance of each strategic resource was developed. The survey was sent electronically to 50 mining professionals located in Peru, Colombia, and the USA. A total of 38 positive responses were collected. In $45 \%$ of the responses, water was the most important resource, 35\% said land, and for $20 \%$ of the mining professionals, the major issue was labour. Therefore, to compute a final score for a mine, the weighted average of the risk associated with all the strategic resources is calculated. The result is a value between 1 and 10 that represents the social risk index associated with the mine. The final formula for the social risk index is:

Social risk index $=0.45 \times$ Social risk of water $+0.35 x$

Social risk of land $+0.20 \times$ Social risk of labour

\section{Applied cases, social risk index calculation in gold mining}

Eight gold mines were selected to estimate the social risk index. The eight mines are located in Argentina, Brazil, Bulgaria, Colombia, and Kyrgyzstan. Gold was the commodity chosen for this analysis, since gold mining is commonly associated with social conflicts due to the high market price of gold and the potential environmental impact of the processing methods used for gold, which are based on chemicals such as cyanide and sulphuric acid. These factors can cause pressure when interacting with local communities. The eight case studies were selected based on three parameters: the size of the mine, communitymine interaction, and social conflicts experienced. Half of the mines have experienced social conflicts, and today they are under evaluation or re-engineering. The other four mines are operating or under construction. The results are mapped in a matrix-based chart, in which each component of the social risk is evaluated between 1 and 10. The final score for the social risk index is plotted using a matrix chart as shown in Figure 4.

\section{Case 1. Krumovgrad Project -Bulgaria}

This is an open pit gold project located in southern Bulgaria, 320 $\mathrm{km}$ from the capital Sofia, and operated by Balkan Mineral and Mining (BBM), a subsidiary of the Canadian company Dundee Precious Metals Inc. (DPM). Exploration in the region began in 1990s by GeoEngineering of Assenovgrad, and Geology \& Geophysics of Sofia, a local exploration firm. Through an extensive drilling and trenching programme, the company identified the presence of gold soil geochemical anomalies in the early-to-mid 1990s. In 2000, BBM was awarded an exploration license for $113 \mathrm{~km}^{2}$, and further exploration work was conducted to define mineralized zones. In 2002 the first mineral resource estimates for the deposit were published and were followed by an update in 2004 that estimated Measured Mineral Resources of more than 230000 gold ounces (oz Au). According to a NI 43101 report the Krumovgrad project has Proved Mineral Reserves of $500000 \mathrm{oz} \mathrm{Au}$. To extract the gold, an open pit mine has been proposed with a capacity to produce $85700 \mathrm{oz} \mathrm{Au}$ and 38700 oz Ag per year by crushing, grinding, and flotation. The open pit mine proposed is $3 \mathrm{~km}$ from the municipality of Krumovgrad, which comprises the town of Krumovgrad and 79 small villages. Small-scale tobacco farming, livestock grazing, and vegetable production are traditional activities in the region (Begum Ozkaynak, 2012).

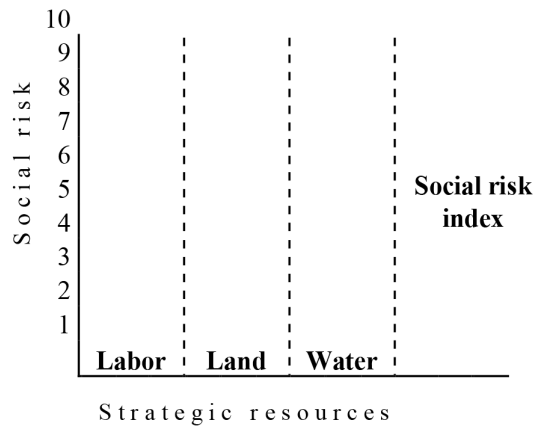

Figure 4-Matrix chart for the social risk index

\section{Table VIII}

\section{Ranking system for parameters}

\begin{tabular}{|c|c|c|c|c|c|}
\hline \multicolumn{2}{|c|}{ Land for mining (ha) } & \multicolumn{2}{|c|}{ Unskilled labour/unemployment rate } & \multicolumn{2}{|c|}{ Population who depend economically on agriculture } \\
\hline Risk & Interval & Rank & Interval & Risk & Interval \\
\hline 10 & $>100001$ & 10 & $<5$ & 10 & $>45001$ \\
\hline 9 & $90001-100000$ & 9 & $8-6-6$ & 9 & $40001-45000$ \\
\hline 8 & $80001-90000$ & 8 & $11-9$ & 8 & $35001-40000$ \\
\hline 7 & $70001-80000$ & 7 & $14-12$ & 7 & $30001-35000$ \\
\hline 6 & $60,001-70,000$ & 6 & $17-15$ & 6 & $25001-30000$ \\
\hline 5 & $50001-60000$ & 5 & $20-18$ & 5 & $20001-25000$ \\
\hline 4 & $40001-50000$ & 4 & $23-21$ & 4 & $15001-20000$ \\
\hline 3 & $30001-40000$ & 3 & $26-24$ & 3 & $10001-15000$ \\
\hline 2 & $20001-30000$ & 2 & $29-27$ & 2 & $5001-10000$ \\
\hline 1 & $<20000$ & 1 & $<30$ & 1 & $<5000$ \\
\hline
\end{tabular}




\section{Development of a socio-economic strategic risk index as an aid for the feasibility assessment}

\section{Technical aspects}

During the exploration programme (2000-2005), more than $70000 \mathrm{~m}$ were sampled by conventional diamond drilling and channel sampling. The total Proved and Probable Mineral Reserves are estimated to be $781000 \mathrm{oz} \mathrm{Au}$, and $450000 \mathrm{oz}$ $\mathrm{Ag}$, at an average grade of $3.36 \mathrm{~g} / \mathrm{t} \mathrm{Au}$ (Balkan Mineral and Mining EAD, 2011). Based on the exploration and technical feasibility results, DPM proposed to mine the ore and waste by conventional open pit methods. Ore will be processed 24 hours per day, 7 days a week by crushing and grinding, followed by froth flotation to produce gold concentrate. The process plant has a capacity of $3100 \mathrm{t} / \mathrm{d}$. Metallurgical recoveries for gold and silver are estimated at $85 \%$ and $70 \%$ respectively. Tailings from the process will be thickened and disposed in a storage facility. Water consumption rates are not included in either the NI 43-101 or environmental impact assessment reports. Fresh water will be supplied from boreholes. Additionally, a water storage facility was proposed to manage heavy rainfall and recycle $98 \%$ of the mine water (AMEC Earth \& Environmeent UK Ltd, 2014). The life of mine (LOM) is calculated at between 7 and 9 years and the mine will employ approximately 230 people. The area for exploration is approximately $11300 \mathrm{ha}$.

\section{Socio-economic aspects}

The area of influence (AoI) of Krumovgrad comprises the town of Krumovgrad and 79 small villages with a total population of approximately 18233 (Denkstatt, 2014). The age distribution in the Aol is as follows: people under working age (14\%), people of working age (17-59 years), and people over working age (33\%). Eighteen per cent of the people over working age are retired. People in the Aol are slightly younger than in the other regions of Bulgaria. Just over half (51\%) of the population is male and $49 \%$ female. Unemployment is one of the socio-economic problems faced by the young population. According to a survey, $32 \%$ of the 18-29 age group is unemployed. The lack of employment opportunities is one of the major reasons for youth migration in the Aol.

Krumovgrad municipality comprises $48.8 \%$ forest area, $47.8 \%$ agricultural lands, $2.2 \%$ towns, villages, and hamlets, and $1.2 \%$ surface water bodies (AMEC Earth \& Environmeent UK Ltd, 2014). Most (88\%) of the arable land is used and cultivated by households. The main economic activities are local agriculture, beekeeping, and pastoralism. These activities depend on the Kromovitsa River, which flows in the vicinity of the Krumovgrad town. Crop cultivation is dominated by tobacco. The skill sets of the residents of the AoI are mainly agricultural (32\%) (Denkstatt, 2014).

\section{Conflict}

Problems began in 2005 after DPM announced the proposed use of cyanide technology for gold processing at Krumovgrad. Local initiatives began anti-cyanide campaigns against BBM, who in 2010 decided to change the gold recovery process. Today, the concerns of communities are based on the pollution of water resources: 'according to interviews with several farmers extensive drilling during the exploration phase has dried up local wells or muddied the water' (Denkstatt, 2014). The climate of the region and the dependence of agricultural activities on the Kromovitsa River are factors that put social pressure on the mining project. Another reason for local concerns is the location proposed for the tailings and waste facilities, which will be about 150 metres from the river and will require displacement of 300 households. The close location of the mine to Krumovgrad town and the potential effects of the operation on agriculture and other traditional activities represent one of the most important social risks.

\section{Social risk analysis}

Table X shows the values for the social risk index and its components, calculated based on the parameters from Table IX. The overall score for the mine was 5.56. From the components, the social risk associated with labour has the highest value. This is explained by the high rank (value 3\%, rank 10) of the number of unemployed people who can work at the mine, which represents $50 \%$ of the social risk of labour. Therefore, the unemployment rate $(32 \%)$, coupled with the low number of locals who can work at a mine (considering $3 \%$ access to employment with suitable skills) are factors that explain the social risk experienced by the mine (see Table X). Furthermore, the high number of people over 60 years old could be considered a factor for conflict, since this population feels that they will be excluded from the benefits the mine would bring to the community. The values for the social risks associated with land and water are led by the mining stage of the project and the distance between mine and community.

\section{Table IX}

\section{Social risk parameters - Krumovgrad}

\begin{tabular}{|l|c|c|c|}
\hline Parameter & Value & Units & Rank $^{1}$ \\
\hline Population size & 18233 & & 2 \\
Population who depends on agriculture & 32 & $\%$ & 2 \\
Water used for mining & 1050 & $\mathrm{~m}^{3} / \mathrm{d}$ & 1 \\
Land used for mining & 11300 & $\mathrm{ha}$ & 1 \\
Access to employment at the time & 3 & $\%$ & 10 \\
Mining stage & Feasibility & & 10 \\
Distance between communities and the mine & 3.0 & $\mathrm{Km}$ & 10 \\
\hline
\end{tabular}

${ }^{1}$ Value of 10 represents the highest social risk, while 1 is associated with low social risk. This applies for all the 8 case studies

\section{Table $X$}

Social risk index and components - Krumovgrad

\begin{tabular}{|l|c|}
\hline Social risk for the strategic resources & Risk \\
\hline Social risk for water & 4.8 \\
Social risk for land & 4.9 \\
Social risk for labor & 8.4 \\
Social risk index & 5.5 \\
\hline
\end{tabular}

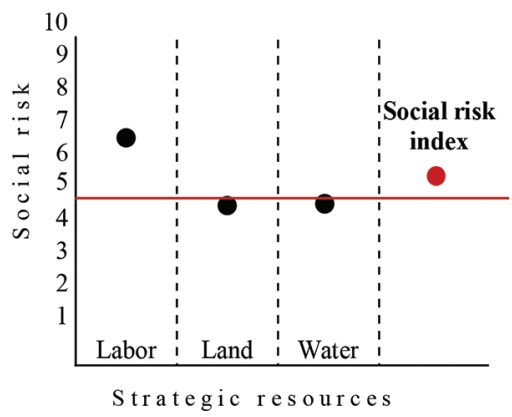

Figure 5-Social risk index - Krumovgrad 


\section{Development of a socio-economic strategic risk index as an aid for the feasibility assessment}

\section{Case 2. Esquel (Suyai) Project - Argentina}

In 2002, Mineral El Desquite SA (MED), a subsidiary of the Canadian mining company Meridian Gold, acquired Brancote Holdings plc, the owner and operator of the Esquel gold project. This project is located in the Sierra de Esquel, Chubut in Argentinean Patagonia. The project is about $7 \mathrm{~km}$ from the town of Esquel, which has a population of approximately 30 000 inhabitants. In the same year of the project's acquisition, Meridian Gold presented an environmental impact assessment (EIA) with plans for developing an open pit mine that would produce 300000 gold ounces a year. The processing method proposed was cyanide leaching. The EIA was rejected by the Argentinian government as a result of public demonstrations against the project and the use of cyanide for mineral processing (Wagner, 2010).

In 2003 'Meridian paused its development efforts following a non-binding referendum wherein the majority of the citizens of the town of Esquel voted not to support the development of the open pit mine' (Meridian Gold, 2006). In 2007, Yamana Gold merged with Meridian Gold, and the Esquel project was renamed Suyai and redesigned as an underground mine. Today the project remains on hold.

\section{Technical aspects}

Currently, there is no technical literature on the initial open pit project. The information presented here was found in technical statements of Meridian Gold. The initial open pit mine was designed to produce 300000 gold ounces a year at $15 \mathrm{~g} / \mathrm{t}$ (Yamana Gold, 2008). Based on Mineral Reserves, the lifespan of the mine was calculated at between eight and nine years. The processing method proposed was cyanide leaching. The expected milling capacity was estimated at $30000 \mathrm{t} / \mathrm{d}$. The contiguous areas that form the project comprise 141000 ha. The mine was expected to create 300 direct and 1200 indirect jobs (Fundacion Patagonia Tercer Milenio, 2008).

\section{Socio-economic aspects}

The information included in this section was taken from the national census in 2001 (the year before the anti-mining demonstration in Esquel). In 2001, the total population of Esquel was $28466,49 \%$ males and $51 \%$ females, with $49 \%$ of the population between 1 and 19 years old. Approximately 15\% of the population is engaged in agriculture (Moran, 2003), $97.7 \%$ has access to water, $83.3 \%$ to sewerage, and $87 \%$ to energy. According to the census, $23.8 \%$ of the households are considered vulnerable. According to Fundacion Patagonia Tercer Milenio, 43\% of people in Esquel live without health services and with insufficient income (Fundacion Patagonia Tercer Milenio, 2008). The unemployment rate is approximately $38 \%$ (Fundacion Patagonia Tercer Milenio, 2008). The illiteracy rate in Esquel in 2001 was approximately $3.1 \%$

\section{Conflict}

The conflict began with failure to communicate the potential environmental and socio-economic effects of the initial open pit mine. For instance, the risks associated with cyanide were not explained, and the initial EIA presented had technical inconsistencies that provoked public concerns and damaged the company's reputation (Morgan, 2003). The antipathy in Esquel against Meridian grew, and the province is now recognized as an anti-mining province.

\section{Social risk analysis}

Table XII shows the values for the social risk index and its components, calculated based on the parameters from Table XI. The overall score for the mine was 6.21. From the components, the social risk associated with labour has the highest value. This is explained by the high rank of unemployment (10). Similarly, the social risk for land is high as a result of the rank for land use (10). Other factors that put pressure on the project are the close distance and the mining stage. Water is the component with the lowest value for social risk, the result of the low consumption rate of water by the mine. In summary, the social risk analysis shows that land and labour are major components of risk. Furthermore, since the mine is in the feasibility stage, it is expected to have high social risk.

\section{Case 3. Angostura project (Colombia)}

High-grade gold veins in the project area, located in the northeast of the Santander province in Colombia, have been exploited since precolonial times. Greystar Resources, a Canadian junior company, began exploration in 1994, but ceased operations in 1999 due to political conflicts and safety concerns in Colombia. Exploration recommenced in 2003, and in 2008 a preliminary

\begin{tabular}{|c|c|c|c|}
\hline Parameter & Value & Units & Rank $^{1}$ \\
\hline Population size & 28466.00 & & 2 \\
\hline Population who depends on agriculture & 15 & $\%$ & 1 \\
\hline Milling capacity & 30000.00 & $t / d$ & 3 \\
\hline Ore grade & 15 & $g / t$ & 10 \\
\hline Local employees required & 300 & & 4 \\
\hline Water used for mining & 10500 & $\mathrm{~m}^{3 / \mathrm{d}}$ & 3 \\
\hline Land used for mining & 141000.00 & ha & 10 \\
\hline Unemployment & 38 & $\%$ & 8 \\
\hline Access to employment rate & $3 \%$ & & 10 \\
\hline Mining stage & Feasibility & & 10 \\
\hline Distance between communities and the mine & 7 & $\mathrm{Km}$ & 8 \\
\hline
\end{tabular}

\section{Table XII}

\section{Social risk index and its components - Suyai}

\begin{tabular}{|l|r|}
\hline Social risk for the strategic resources & Risk \\
\hline Social risk for water & 4.95 \\
Social risk for land & 6.9 \\
Social risk for labour & 7.85 \\
Social risk index & 6.21 \\
\hline
\end{tabular}

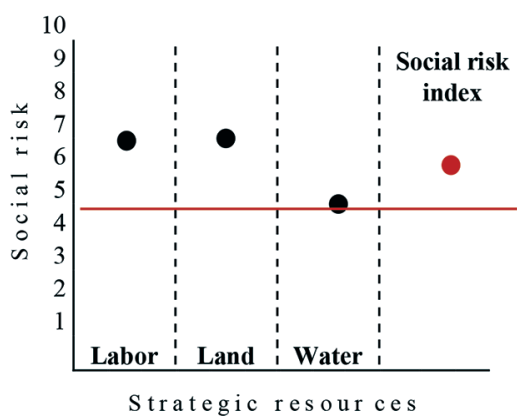

Figure 6-Social risk index and its components - Suyai 


\section{Development of a socio-economic strategic risk index as an aid for the feasibility assessment}

economic assessment for an open pit mine was completed (Golder Associates, 2012). In 2011, after environmentalpermissions had been lodged, Ingeominas (the national agency that regulates mining activities in Colombia) did not approve the EIA, arguing that the open pit mine location endangered a fragile ecosystem that is vital for the water cycle. The Angostura project provoked the mobilization of local organizations and people in Bucaramanga, the largest city in the vicinity (67 km distant). This is the most notorious anti-mining case in Colombia. In 2011, Greystar Resources changed its name to Eco Oro Minerals Corp. and initiated an assessment to change the initial open pit project to an underground high-grade operation. Despite the re-engineering and the new feasibility study, the project remains halted.

\section{Technical aspects}

The pre-feasibility study for the open pit mine was completed in 2009 and considered two possible processing routes: cyanide heap leaching for low-sulphur material and grinding and flotation for high-sulphur ore. Mineral resources were calculated at 7.7 million ounces $\mathrm{Au}$ at $1.1 \mathrm{~g} / \mathrm{t}$ and 34.5 million ounces $\mathrm{Ag}$ (Ejolt, 2013). Approximately 50000 ha of land were used for exploration. The project would move $70000 \mathrm{t}$ of ore a day, which guaranteed the operation of the mine for approximately 15 years.

\section{Socio-economic aspects}

The population affected by the Angostura project is approximately 77 000, including the towns of Angostura, La Baja, Centro Cerrillos, Santa Ursula, Pantanos, and California. California is the closest town, located $13 \mathrm{~km}$ from the project. The major economic activities (approximately 65\%) in the region are agriculture, livestock grazing, fishing, and small-scale gold and silver mining (Agencia Atenea, 2013). The distribution of the population is $54 \%$ females and $46 \%$ males. The population is young, with $33 \%$ under the age of 18 , and $17 \%$ between 25 and 34 years. Just under half (48\%) of the population has completed primary school, and $36 \%$ high school. Four per cent do not have access to any kind of health service. The unemployment rate in the region is estimated to be 10\% (Agencia Atenea, 2013).

\section{Conflict}

This massive gold deposit is located $67 \mathrm{~km}$ from the city of Bucaramanga (503 000 inhabitants). The elevation of the region is between 2400 and 3500 masl. A critical condition for the Angostura project is its close location to a fragile alpine tundra ecosystem (called paramos) that provides water to over 2.2 million people (Ejolt, 2013). The local economies of California and Vetas, the closest municipalities to the project, are based primarily on agricultural activities, followed by small-scale mining. Locals argued that the open pit mine would affect the availability of land for small-scale operations. In Bucaramanga, communities and local organizations conducted social protests against the Angostura project, and mobilized more than 30 000 people in 2011 . The main concern in this case was the potential impact of the initial open pit mine and possible cyanide release into the ecosystem, with damage to its water production capability.

\section{Social risk analysis}

Table XIV shows the values for the social risk index and its components, calculated based on the parameters from Table
XIII. The overall score for the mine was 7.39. The social risk in Angostura is led by labour. This is explained by the high percentage of the population that depends on agriculture, and the low employment rate anticipated by the mine, due to competition for labour resources. The high values for the social risk of water and labour are the result of the large population, and the large number of people who depend on agriculture.

\section{Case 4. La Colosa Project (Colombia)}

La Colosa is a massive world-class deposit discovered in 2006, located $14 \mathrm{~km}$ west of the municipality of Cajamarca (population 19546 ) in the Tolima province in central-west Colombia. The project is being developed by the South African company AngloGold Ashanti (AGA). La Colosa is currently at prefeasibility stage, with technical evaluations focused on mineral resources extension and mining method selection. According to the mineral deposit geometry and the initial information on mineral resources provided by AGA, mining will be through conventional open pit methods. The province of Tolima is known as the 'agricultural belt' of Colombia. Rice, coffee, fruits, plantain, yucca, and beans are the main products from this region (Ejolt, 2015). Livestock grazing for milk and meat production is another major economic activity. Approximately $50 \%$ of the population depends on agriculture (National Committee on Statistics, 2010).

\section{Table XII}

\section{Social risk parameters - Angostura}

\begin{tabular}{|l|c|c|c|}
\hline Parameter & Value & Units & Rank \\
\hline Population size & 77000 & & 7 \\
Population who depends on agriculture & 65 & $\%$ & 10 \\
Milling capacity & 70000 & $\mathrm{t} / \mathrm{d}$ & 7 \\
Local employees required & 254 & & 4 \\
Water used for mining & 24500 & $\mathrm{~m} 3 / \mathrm{d}$ & 5 \\
Land used for mining & 50000 & $\mathrm{ha}$ & 4 \\
Unemployment & 10 & $\%$ & 3 \\
Access to employment & $3 \%$ & & 10 \\
Mining stage & Prefeasibility & & 9 \\
Distance between communities and the mine & 13 & $\mathrm{Km}$ & 4 \\
\hline
\end{tabular}

Table XIV

Social risk index and its components - Angostura

\begin{tabular}{|l|r|}
\hline Social risk for the strategic resources & Risk \\
\hline Social risk for water & 6.95 \\
Social risk for land & 7 \\
Social risk for labour & 9.05 \\
Social risk index & 7.39 \\
\hline
\end{tabular}

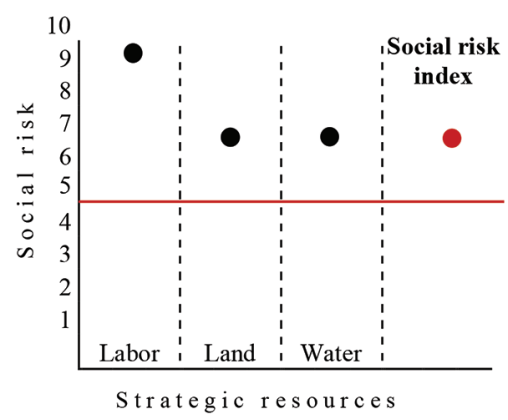

Figure 7-Social risk index - Angostura 


\section{Development of a socio-economic strategic risk index as an aid for the feasibility assessment}

\section{Technical aspects}

This is a large gold deposit with Inferred Mineral Resources of 26.8 million ounces Au (AngloGold Ashanti, 2012). The initial mining scenario proposed an open pit mine with annual gold production of 1 million ounces. The estimated annual production rate is $70 \mathrm{Mt}$ of ore (approximately $190 \mathrm{kt} / \mathrm{d}$ ). Based on this production profile, the mine life was calculated to be 25 years. The total area in which the company has been working is approximately $60000 \mathrm{ha}$. Water consumption will be approximately $0.5 \mathrm{~m}^{3} / \mathrm{s}$ or $15.5 \mathrm{~m}^{3}$ per gold ounce.

\section{Socio-economic aspects}

The area of influence of the project includes Cajamarca town and five villages - Diamante Cristales, La Paloma, La Luisa, Los Alpes, and La Bolívar y Altamira, with a total regional population of 22500 (Mendoza, 2014). In the Aol 52\% of the people are women, while $48 \%$ are male, $44 \%$ of the sample younger than 18 years, $50 \%$ between 18 and 60 years, and $6 \%$ are older than 60 years. Water is accessible to $88.04 \%$ of the population, while access to sewerage and electricity are $90.52 \%$ and $97.96 \%$ respectively. A total of $5.48 \%$ of the population are illiterate, and $65 \%$ have not completed high school. The percentage of the children between 7 to 11 years and between 12 and 18 years who do not attend school is $7.2 \%$ and $16.17 \%$ respectively. The main reason for not going to school is the cost of education, followed by the location of schools. In the AoI, $15 \%$ of the population is unemployed.

\section{Conflict}

The size of the gold deposit itself represents an opportunity for conflict. Pollution risks, resource intensity (land, water), and socio-political interest are higher than in smaller operations. In addition, the economic activities of Cajamarca (located 15 minutes away from La Colosa) are based on agriculture (23.32\%) and livestock grazing (29.85\%). This region is considered an important agricultural zone for the entire country, producing coffee, beans, corn, tomatoes, blackberries, oranges etc. In addition to its remarkable agricultural output, the region produces milk and meat from livestock grazing (Mendoza, 2014). These economic conditions and the potential open pit / cyanide leaching project make the use of water a major concern for all stakeholders. Rice and coffee producers, farmers, and the University of Tolima have expressed strong opposition to the project, claiming that the company was not transparent during the exploration stage, and that pollution from the mine will adversely affect the traditional economic activities in the region (Mendoza, 2014).

\section{Social risk analysis}

Table XVI shows the values for the social risk index and its components, based on the parameters from Table XV. The overall score for the mine was 6.29. Of the three components, the social risk associated with water has the highest value. The size of the projected mine, with its potential capacity to process $190 \mathrm{kt}$ daily at a grade of $2.86 \mathrm{~g} / \mathrm{t}$, is the major reason for conflict (rank $10)$. The risk associated with land is explained by the land area used by the project (rank 5), and the current stage of the project (10). The risk associated with labour has the lowest score, since unemployment in the region is low (rank 2), and the mine has the capacity to employ at least $15 \%$ of the unemployed people. The social risk profile for La Colosa suggests that there is an imbalance between the mine and community size. The social risk of water, which is directly associated with the mine size, is high, while the risk for labour is relatively low.

\section{Case 5. Paracatu Mine (Brazil)}

Portuguese Bandeirantes (adventurers) arrived in the Paracatu region of central Brazil in the mid-eighteenth century after the discovery of alluvial gold deposits. This migration led to the founding of the town of Paracatu. Small-scale and artisanal miners continued working in the region in the 1900s. In 1970, more aggressive exploration took place. In 1985, a feasibility study proposed an open pit mine operation. Production began in 1987 at 3884 ounces per annum and reached 497940 ounces in 2013 (Sims, 2014).

\section{Technical factors}

Several companies have operated the mine. The current operator, Kinross Gold, acquired the property between 2003 and 2004 from Rio Tinto and Echo Bay. The mine produces $55 \mathrm{Mt}$ of ore annually that feeds two processing plants (grinding/flotation and carbon in leach for treating oxide and sulphide ores respectively. The mill capacity is $170000 \mathrm{t} / \mathrm{d}$ (Sims, 2014). Two tailings facilities receive the waste material. According to the NI-43101 report, the mine has 10.4 million ounces in Mineral Reserves and a life of mine of 19 years (Sims, 2014).

\section{Table XV}

\section{Parameters for social risk parameters - La Colosa}

\begin{tabular}{|l|c|c|c|}
\hline Parameter & Value & Units & Rank \\
\hline Population size & 19546 & & 5 \\
Population who depends on agriculture & 50 & $\%$ & 3 \\
Milling capacity & 190000.00 & $\mathrm{t} / \mathrm{d}$ & 10 \\
Local employees required & 476 & & 5 \\
Water used for mining & 66500 & $\mathrm{~m} 3 / \mathrm{d}$ & 10 \\
Land used for mining & 60000.00 & $\mathrm{ha}$ & 5 \\
Unemployment & 8 & $\%$ & 3 \\
Access to employment & $30 \%$ & & 1 \\
Mining stage & Prefeasibility & & 9 \\
Distance between communities and the mine & 14 & $\mathrm{Km}$ & 4 \\
\hline
\end{tabular}

\section{Table XVI}

\section{Social risk index and its components - La Colosa}

\begin{tabular}{|l|c|}
\hline Social risk for the strategic resources & Risk \\
\hline Social risk for water & 7.8 \\
Social risk for land & 5.7 \\
Social risk for labour & 3.4 \\
Social risk index & 6.19 \\
\hline
\end{tabular}

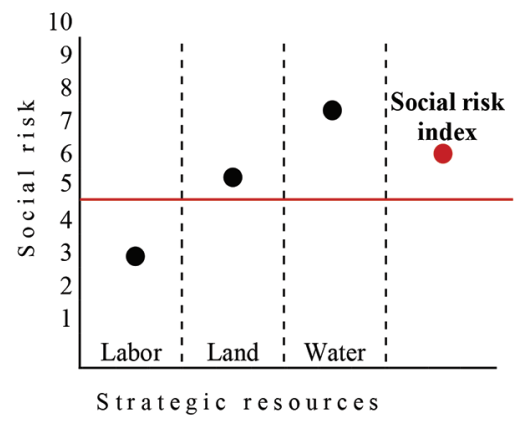

Figure 8-Social risk index - La Colosa 


\section{Development of a socio-economic strategic risk index as an aid for the feasibility assessment}

\section{Socio-economic factors}

The mine is $1 \mathrm{~km}$ from the city of Paracatu (Good River), located in northwestern Brazil in the famous mining state of Minas Gerais, with a population of approximately 85000 (D'Oliveira, 2010). According to the 2001 census, $45 \%$ of the population was under 19 years and the male to female ratio was 1.02. Sixteen per cent of the population is currently attending elementary school and $5 \%$ is attending high school. The unemployment rate in Paracatu is approximately $15 \%$. This is a tropical savanna area that supports farming and livestock grazing. The main products are soybeans, corn rice, and coffee. Kinross employs 3400 people ( $4 \%$ of the total population). The mine accounts for $8 \%$ of the total GDP of Paracatu, while industrial and agriculture activities make up $18.6 \%$. Service companies represent the largest economic sector with $49.8 \%$ of Paracatu's GDP. Ninety-eight per cent of the population has access to water, and $70 \%$ access to sewerage.

\section{Social risk analysis}

Table XVIII shows the values for the social risk index and its components, calculated based on the parameters from Table XVII. The overall score for the mine was 4.93. Of the three components, the social risk of water has the highest value. The amount of water consumed per day (rank 10), and the size of

\section{Table XVII}

\section{Parameters of social risk - Paracatu}

\begin{tabular}{l|c|c|c|}
\hline Parameter & Value & Units & Rank \\
\hline Population size & 85000 & & 9 \\
Population who depends on agriculture & 18.6 & $\%$ & 5 \\
Milling capacity & 170000 & $\mathrm{t} / \mathrm{d}$ & 10 \\
Local employees required & 2040 & & 10 \\
Water used for mining & 88803 & $\mathrm{~m}^{3} / \mathrm{d}$ & 10 \\
Land used for mining & 12037 & $\mathrm{ha}$ & 1 \\
Unemployment & 20 & $\%$ & 2 \\
Access to employment & 15 & $\%$ & 1 \\
Mining stage & $>20$ & & 1 \\
Distance between communities and the mine & 2 & $\mathrm{Km}$ & 10 \\
\hline
\end{tabular}

\section{Table XVIII}

\section{Social risk components - Paracatu}

\begin{tabular}{l|c} 
Social risk for the strategic resources & Risk \\
\hline Social risk for water & 6.5 \\
Social risk for land & 3.5 \\
Social risk for labour & 3.9 \\
Social risk index & 4.93 \\
\hline
\end{tabular}

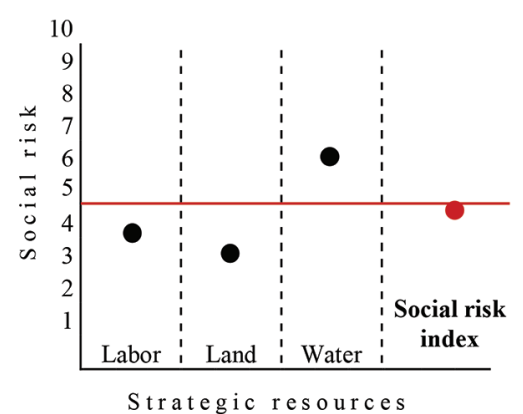

Figure 9-Social risk in Paracatu the community (rank 9) are the main drivers for social risk at Paracatu. The low score for the index is the result of the mining stage effect. Since the mine has been operating for more than 20 years, the conflicts and different interests of the mine and communities in terms of labour and land demands have already been addressed. At Paracatu, water is the most important social risk factor, since even though the land and labour risks are low, water pushes the index close to 5. Another conclusion from this case study is that mines are expected to experience social risk for water until closure, or even beyond closure when the mine no longer has an active team present in the area, while the risks for land and labour may tend to be lower after several years of operation.

\section{Case 6. Kumtor Mine (Kyrgyzstan)}

Kumtor is one of the largest open pit gold mines in the world. The mine is located in northeastern Kyrgyzstan (former USSR) at an elevation of $4400 \mathrm{~m}$ and approximately $80 \mathrm{~km}$ from the Issyk Kul lake, the tenth largest lake in the world. In 2014, gold production was 567693 ounces. Exploration by an expedition of the state geological department began in 1978. In 1990, after extensive trenching, diamond drilling, and underground development, an initial reserve estimation was issued by the USSR (Centerra Gold Inc., 2015). In 1992, after the USSR broke up, the Kyrgyz Republic was formed, and Centerra Gold began working on the deposit. After several years of assessment, a final feasibility study was completed in 1995. In 1996, project construction concluded, and production began in 1997.

\section{Technical aspects}

The mine uses conventional open pit mining methods, and moves around $318 \mathrm{kt} / \mathrm{d}$. The nominal plant capacity is approximately 15 $900 \mathrm{t} / \mathrm{d}$ at $4.00 \mathrm{~g} / \mathrm{t} \mathrm{Au}$. Processing consists of crushing, grinding, pyrite flotation, and two-stage regrinding of flotation concentrate. Two carbon-in-leach circuits extract the gold, and final gold recovery is by electrowinning and refining. Based on current Mineral Reserves (6.1 million ounces $\mathrm{Au}$ ), mining activities at Kumtor will extend until 2023.

\section{Socio-economic aspects}

The Issyk-Kul province in Kyrgyzstan had a population of around 450000 in 2009 (Nippon Koei, 2009). The project is located in the Tong and Jeti Oguz districts, which have a total population estimated at 131000 (National Committee on statistics 2010). Around $40 \%$ of the population is below working age, $50 \%$ are working age, and 10\% are retired. Agriculture is the main

Table XIX

Parameter of social risk - Kumtor

\begin{tabular}{|l|c|c|c|}
\hline Parameter & Value & Units & Rank \\
\hline Population size & 131000 & & 10 \\
Population who depends on agriculture & 20 & $\%$ & 6 \\
Milling capacity & 15900 & $\mathrm{t} / \mathrm{d}$ & 2 \\
Ore grade & 4 & $\mathrm{~g} / \mathrm{ton}$ of Au & 4 \\
Local employees required & 2160 & & 5 \\
Water used for mining & 5565 & $\mathrm{~m} 3 / \mathrm{d}$ & 2 \\
Land used for mining & 26000 & $\mathrm{ha}$ & 2 \\
Unemployment & 40 & $\%$ & 8 \\
Access to employment & 5 & $\%$ & 9 \\
Mining stage & $>20$ & & 1 \\
Distance between communities and the mine & 80 & $\mathrm{Km}$ & 1 \\
\hline
\end{tabular}




\section{Development of a socio-economic strategic risk index as an aid for the feasibility assessment}

\section{Table XX}

\section{Social risk and components - Kumtor}

\begin{tabular}{l|c} 
Social risk for the strategic resources & Risk \\
\hline Social risk for water & 2.6 \\
Social risk for land & 3.2 \\
Social risk for labour & 4.2 \\
Social risk index & 3.13
\end{tabular}

activity, employing more than $50 \%$ of the working population

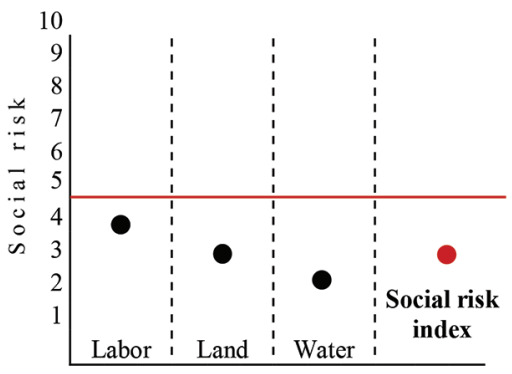

Strategic resources

Figure 10-Social risk - Kumtor

(Nippon Koei, Ram Engineering, 2009). Unemployment is high, at approximately $40 \%$. Access to health and school facilities are similar to other Kyrgyz regions, but rural areas have additional limitations. The Kumtor mine is the largest private sector employer in the country, with 2500 full-time employees, 97\% of whom are Kyrgyz nationals. The company supports collective bargaining with unions. The mine accounted for $24 \%$ of the country's industrial output and 7.7\% of the GDP in 2013.

\section{Social risk analysis}

Table XX shows the values for the social risk index and its components, calculated based on the parameters from Table XIX. The overall score for the mine was 3.13. Of the three components, the social risk of labour has the highest value. The size of the population (rank 10) and the unemployment rate (rank 8) account for the high social risk of labour. Water and land are not major issues, since they are not consumed at high rates (both ranked at 2), and the mine is located far from the communities. Kumtor is the mine with the lowest social risk in the case studies, the result of a low water consumption rate, the location of the mine, and the age of the operation.

\section{Case 7. Gramalote (Colombia)}

Gramalote is located near the town of Providencia in the province of Antioquia in central-west Colombia. The project area has a long history of artisanal gold mining. Hydraulic techniques were used by the first miners in the region in the 1900s. Metallica Resources conducted preliminary exploration work in 1995. Between 1996 and 2000, three other companies (Gridiron Exploration Ltd, Placer Dome, and Penõles) conducted evaluations at Gramalote. Exploration work was halted as a result of political risk and violence in Colombia. In 2003, AngloGold began exploration at Gramalote, spending more than US\$4.3 million. In 2007 and 2008, B2Gold entered into an agreement that gave the company management responsibility for exploration on the project. Pre-feasibility and feasibility reports from 2011 and 2012 demonstrated positive economic results
(Gustavson Associates, 2012). In 2015, B2Gold was granted an environmental license to operate. The area of influence comprises a town and 14 villages. The main economic activities are agriculture, livestock grazing, and small-scale mining (AngloGold Ashanti, Integral, 2015).

\section{Technical aspects}

The project is currently held as a joint venture between AGA (51\%) and B2Gold (49\%). It is operated by Gramalote (Colombia) Ltda. The Gramalote area comprises 17 concessions (35 321.74 ha). The exploration campaign completed 132 diamond drillholes for $44196 \mathrm{~m}$ in 2011. According to the preliminary economic assessment report prepared by B2Gold in 2014, Gramalote has Mineral Resources (Measured, Indicated, and Inferred) for approximately 4.7 million ounces Au. The life of the mine is estimated at 14 years. The project has three mineralized zones that are envisioned to be mined by conventional open pit methods. The ore will be treated in a gravity and flotation process at a milling rate of $46 \mathrm{kt} / \mathrm{d}$. The annual production is estimated to be $350 \mathrm{kt}$ for 450000 gold ounces (Gustavson Associates, 2014). According to the EIA, the construction of Gramalote will create 3500 direct and 7000 indirect jobs. Once in operation, 700 direct jobs will be created.

\section{Socio-economic aspects}

The population in the area of influence was estimated to be 55208 (AngloGold Ashanti, 2015). The distance between the communities and the mine is approximately $12 \mathrm{~km}$. People 15 years or younger and 64 years old or more together account for $35.6 \%$ of the total population. Students represent $22.5 \%$ of the population. Approximately three-quarters (73.3\%) of the population are employed, while $2.3 \%$ are looking for employment. Child labour is one of the social problems in this region. Education levels in the region are low - more than $82 \%$ of the population has less than nine years of education. Health services are available to $7.1 \%$ of the population, and $80 \%$ have

\section{Table XXI}

\section{Social risk components - Gramalote}

\begin{tabular}{|l|r|}
\hline Social risk for the strategic resources & Risk \\
\hline Social risk for water & 5.2 \\
Social risk for land & 4.8 \\
Social risk for labour & 4 \\
Social risk index & 4.82 \\
\hline
\end{tabular}

\section{Table XXII}

\section{Parameter for social risk - Gramalote}

\begin{tabular}{|l|c|c|c|}
\hline Parameter & Value & Units & Rank \\
\hline Population size & 55208 & & 5 \\
Population who depends on agriculture & 56.8 & $\%$ & 7 \\
Milling capacity & 49000 & $\mathrm{t} / \mathrm{d}$ & 5 \\
Local employees required & 205 & & 4 \\
Water used for mining & 17150 & $\mathrm{~m}^{3} / \mathrm{d}$ & 4 \\
Land used for mining & 26000 & $\mathrm{ha}$ & 2 \\
Unemployment & 3 & $\%$ & 1 \\
Access to employment & 27 & $\%$ & 2 \\
Mining stage & Development & & 6 \\
Distance between communities and the mine & 12 & $\mathrm{Km}$ & 5 \\
\hline
\end{tabular}




\section{Development of a socio-economic strategic risk index as an aid for the feasibility assessment}

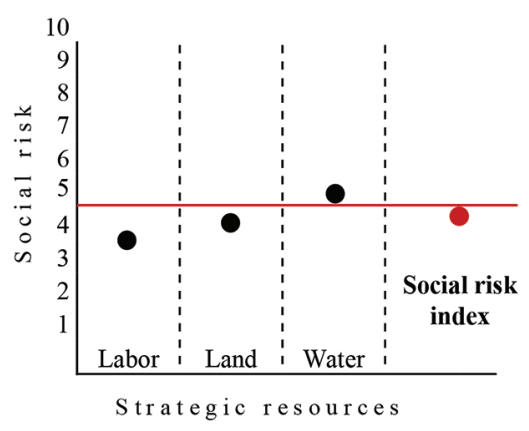

Figure 11-Social risk - Gramalote

access to water. Only $35 \%$ of the population has access. Only $35 \%$ of the population has access to sewerage services. Agriculture $(23.8 \%)$, mining $(23.1 \%)$, livestock grazing $(33 \%)$, and trade of goods and services (10.9\%) are the main economic activities in the region (AngloGold Ashanti, Integral, 2015).

\section{Social risk analysis}

Table XXII shows the values for the social risk index and its components, calculated based on the parameters from Table XXI . The overall score for the mine was 4.82. Of the three components of the index, the social risk of water has the highest value. The size of the population that depends on agriculture (rank 7) is one of the major parameters provoking risk conditions in both land and water. The lowest risk is associated with labour, the result of the low unemployment rate in the area of influence. Gramalote is now under development, a high-risk mining stage.

\section{Case 8. Santa Rosa Gold Project (Red Eagle Mining- Colombia)}

The project is located $20 \mathrm{~km}$ southeast of the town of Santa Rosa de Osos in the municipality of the same name in the province of Antioquia, northwest Colombia. The mining potential in the Santa Rosa area was recognized around 1600 . Gold was produced in the 18th century from upland placers and from high-grade oxide ores in the 1940s (Lycopodium Minerals Canada, 2014). Artisanal mining continues today. In July 2010, Read Eagle began the first modern exploration campaign. Between September 2011 and May 2013, the company completed $45609 \mathrm{~m}$ of drilling. In October 2013, the company announced positive results from a preliminary economic assessment. After the environmental impact assessment submission, Red Eagle was granted permission to start construction in August 2014. In terms of social context, 18 villages are located in the vicinity of the project. The area of influence is estimated to be 6000 ha.

\section{Technical aspects}

The Santa Rosa gold project comprises a total area of 33000 ha. After the exploration campaign, Red Eagle estimated Proven and Probable Mineral Reserves of 405 million gold ounces. The life of mine was estimated at 7 years (50600 ounces $\mathrm{Au}$ per annum). An underground operation is planned (Lycopodium Minerals Canada, 2014), using mechanized shrinkage with delayed fill (MSDF). The processing plant was designed for an initial milling capacity of $1000 \mathrm{t} / \mathrm{d}$, with provision for future expansion to 2000 $\mathrm{t} / \mathrm{d}$. The flow sheet includes grinding and flotation followed by concentrate regrinding. There will be four operation crews to cover back-to-back 12-hour shifts.

\section{Table XXIII}

Parameter for social risk - Santa Rosa

\begin{tabular}{|l|c|c|c|}
\hline Parameter & Value & Units & Rank \\
\hline Population size & 30000 & & 2 \\
Population who depends on agriculture & 77 & $\%$ & 5 \\
Milling capacity & 2000 & $\mathrm{t} / \mathrm{d}$ & 1 \\
Local employees required & 390 & & 4 \\
Water used for mining & 700 & $\mathrm{~m} / \mathrm{d}$ & 1 \\
Land used for mining & 33000 & $\mathrm{ha}$ & 3 \\
Unemployment & 20 & $\%$ & 4 \\
Access to employment & 7 & $\%$ & 8 \\
Mining stage & Development & & 6 \\
Distance between communities and the mine & 20 & $\mathrm{Km}$ & 1 \\
\hline
\end{tabular}

\section{Table XXIV}

\section{Social risk and components - Santa Rosa}

\begin{tabular}{|l|r|} 
Social risk for the strategic resources & Risk \\
\hline Social risk for water & 3.15 \\
Social risk for land & 4 \\
Social risk for labour & 6.15 \\
Social risk index & 4.05 \\
\hline
\end{tabular}

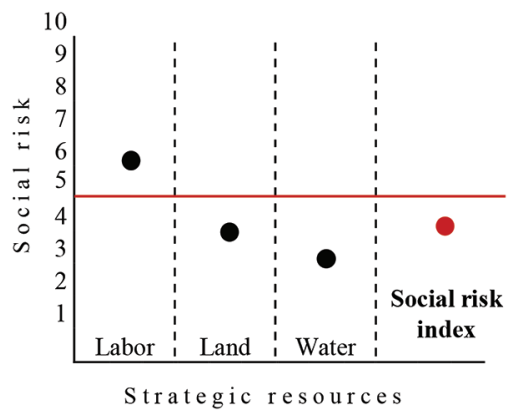

Figure 12-Social risk index - Santa Rosa

\section{Socio-economic aspects}

The population in the area of influence is 1077 , of which $56 \%$ are female and $46 \%$ are male. Thirty-six per cent of the population has access to water supply, $3 \%$ to sewerage, $97 \%$ to electricity, $74 \%$ to gas, and $31 \%$ to sanitation and collection services (Lycopodium Minerals Canada, 2014). In 2012, the unemployment rate in Santa Rosa was approximately $20 \%$ (Santa Rosa de Osos Municipality, 2012). The major economic activities in the region (approximately 77\%) are dairy farming, forestry, poultry farming, production of tomatoes or tamarillos, and pig farming (DANE, 2006). According to the feasibility study report, the project has the capacity to create 150 direct jobs and approximately 500 indirect jobs.

\section{Social risk analysis}

Table XXIV shows the values for the social risk index and its components, calculated based on the parameters from Table XXIII. The score of the social risk index was 4.05. The social risk associated with labour is the highest component of the index. This is explained by the high number of people involved in agriculture and the unemployment rate in Santa Rosa. All the parameters but the ore grade and mining stage were ranked 


\section{Development of a socio-economic strategic risk index as an aid for the feasibility assessment}

\begin{tabular}{|c|c|c|c|c|}
\hline \multicolumn{5}{|c|}{$\begin{array}{l}\text { Table XXV } \\
\text { Social risk indexes - case studies }\end{array}$} \\
\hline Project & Risk of water & Risk of land & Risk of labour & Social risk index \\
\hline Krumovgrad & 4.8 & 4.9 & 8.4 & 5.6 \\
\hline Suyai & 5 & 6.9 & 7.9 & 6.2 \\
\hline Angostura & 7 & 7 & 9.1 & 7.4 \\
\hline Colosa & 7.8 & 5.7 & 3.4 & 6.2 \\
\hline Paracatu & 6.5 & 3.5 & 3.9 & 4.83 \\
\hline Kumtor & 2.6 & 3.2 & 6.2 & 3.5 \\
\hline Gramalote & 5.2 & 4.8 & 4 & 4.8 \\
\hline Santa Rosa & 3.2 & 4 & 6.2 & 4 \\
\hline
\end{tabular}

below 5. In comparison to the other projects, Santa Rosa is the smallest mine in terms of production, which implies less consumption of strategic resources. The case of Santa Rosa shows that, even when the mining operation is small and located far from the communities, social risk might be high as a result of the population size and unemployment.

\section{Conclusions}

Community relations are very important in the development of mining operations. However, it is extremely difficult to quantify the level of acceptance by a community towards a mining company.

The initial results from this study demonstrate a positive identification of those projects involved in severe social conflicts. Social conflict typically occurs during the feasibility or pre-feasibility phase, as these stages involve permitting and social consultation. It is therefore important that consultation takes place in the prospecting and exploration phases. As a consequence of social conflicts with local communities, mining companies have lost millions of dollars in investment opportunities and production. Additionally, social conflict damages company reputation, which could in turn adversely affect the company's market value. The prevention and management of potential social conflict that may occur as a result of interactions between mining operations and communities should be considered a top priority for any mining company.

A summary of the social risk index evaluation from the eight case studies is shown in Table XXV. The mines with scores above five experienced major social conflicts that translated into either the suspension or abandonment of the project. The social risk associated with labour presents the highest mean value among all the mines. This is explained by the high unemployment rates in local communities, and the sizes of the populations working in activities associated with the use of strategic resources (agriculture).

After the calculation of the social risk index and its three components in all eight case studies, it is concluded that the mining projects that were halted or that were unable to gain the permission to operate from the communities had a social risk index above five. Thus, an index value of five is used as the cut-off threshold to mark the point at which the social risk of a mining project represents a significant risk. In the particular case of gold mining, a value higher than five resulted either in the abandonment or suspension of the project.

Socio-economic risk in mining can occur as a result of competition between local communities and companies for three key strategic resources: water, land, and labour. These are typically the strategic resources required for the development of a mining project and, of course, they are also required for the development of any community. Initially in this study, energy resources, besides water, land, and labour, were considered as a competition factor. However, no relationship was found between energy and social conflict. This study finds that water is the most critical strategic resource, due to its daily use in living and economic activities. In most cases, this is the strategic resource that best explains the occurrence of social conflicts. Additionally, according to this study, water is also considered by the mining industry to be the most valuable resource, followed by land and labour. The results suggest that, based on the information concerning competition for strategic resources and the interaction between actors, the index identifies the potential for social conflict.

The social risk index developed in this paper can assist the mining industry with a tool for the assessment of possible conflict risk scenarios. The index could be used as a risk analysis tool that can provide information about what specific components or strategic resources must be prioritized in order to reduce social risk, and hence as a guide to develop strategies to assist with social risk management.

Factors of lower impact, not included in the project but which could be considered for future studies, are:

$>$ Social-political profile of the country

$>$ Environmental vulnerability of the mining site and its surroundings

> Mining tradition of the region

- Mining regulations of the country

> Mining rights and superficial land use ownership.

\section{References}

Agencia Atenea. 2013. Estudio socio-demografico, provincia de Soto Norte. Girón, Santander, Colombia

AMEC EARTH \& ENvIronmENT UK LTD. 2014. Non-technical summary, environmental and social impact assessment - Krumovgrad Gold Project, Bulgaria. Knutsford Cheshire.

AngloGold Ashanti. 2008. Estudio socioeconomico y Ambiental de Cajamarca.

AngloGold Ashanti. 2012. Project profile, La Colosa Colombia. https:// www.agareports.com , download, AGA-OP12-col-lacolosa.pdf

AngloGold AsHAnTi. 2015. Integral environmental impact assessment, Gramalote gold project.

AngloGold Ashanti. 2013. 2012 Annual Report.

Balkan Mineral and Mining EAD. 2011. Krumovgrad Gold Project, Definitive Feasibility Study 43-101 Technical Report.

BARRICK Gold CoRPoration. 2015. Annual Report 2014. http://www.annualreports. com/HostedData/AnnualReportArchive/b/NYSE_ABX_2014.pdf

BEgum OzKAYNAK, B.R. 2012. Mining conflicts around the world: Common grounds from an environmental justice perspective. Ejolt Report no. 7. http://www.ejolt. org/wordpress/wp-content/uploads/2012/11/121115_Ejolt-7_High.pdf

BЕкEFI, T. and EpsTEIN, M.J. 2006. Integrating social and political risk into management decision-making. CIMA, Toronto, Ontario, Canada. https://www. cimaglobal.com/Documents/ImportedDocuments/Tech_MAG_Integrating_Social Political_Risks_Sept06.pdf 


\section{Development of a socio-economic strategic risk index as an aid for the feasibility assessment}

BLOOMBERG. 2015. Water risk valuation tool: Integrating natural capital limits into financial analysis of mining stocks. https://www.bbhub.io/sustainability/ sites/6/2015/09/Bloomberg_WRVT_09162015_WEB.pdf

CenterRa Gold Inc. 2015. Technical report on the Kumtor mine, Kyrgyz Republic. https://www.centerragold.com/cg-raw/cg/centerra_kumtor_technical_report_ final_march_20_2015.pdf

Compania de Minas Buenaventura. 2015. Reporte de sostenibilidad 2014. https://www. unglobalcompact.org/participation/report/cop/create-and-submit/active/159701

D'OlIVEIRA, G.V.C. 2010. Explaining mining company and community relations in Paracatu Brazil: situational context and company practices. https://www. semanticscholar.org/paper/Explaining-mining-company-and-communityrelations-Oliveira/fa9f143e7b854fc95c527cac64baf30e68901616

DANE. 2006. Censo General 2005, perfil Santa Rosa de Osos Antioquia. https:// www.dane.gov.co/files/censo2005/PERFIL_PDF_CG2005/05686T7T000.PDF

DAniel, F. 2014. Cost of company-community conflict in the extractive sector. The CSR Initiative at the Harvard Kennedy School, Cambridge, MA.

Davis, K. 1975. Five propositions for social responsibility. Business Horizons, vol. 18, no. 3. pp. 19-24.

Denkstatt GmBH. 2014. Socio economic baseline report Krumovgrad Project. https:// s21.q4cdn.com/589145389/files/doc_documents/EN/2017/12/SIA_Baseline_ EN.pdf

EjoLt. 2013. The Angostura mining project in the Paramo de Santurban, Colombia. http://www.ejolt.org/2013/02/the-angostura-mining-project-in-the-paramo-of santurban-colombia/

Ejolt. 2015. La Colosa mining project in Cajamarca (Colombia). http://www.ejolt. org/2015/02/la-colosa-mining-project-cajamarca-colombia/

El EconomisTA. 2015. Conflictos en Peru han retrasado inversiones mineras por mas de 21,500 mdd.5 October 2015. p. 1.

Environment CANADA. 2004. Threats to water availability in Canada. NWRI Scientific Assessment Report Series, no. 3. Vancouver.

EY. 2015. Guia de Inversiones y Negocios en el Peru 2015/2016. https:// www.academia.edu/23205359/EY_Guia_de_Negocios_e_Inversion_en_el_ Peru_2015_2016

EY. 2015. Business risks facing mining and metals 2015-2016. https://www. shinnihon.or.jp/shinnihon-library/publications/research/2015/pdf/2015-0914-en.pdf

Davis, R. and Franks, D. 2014. Cost of company-community conflicts in the extractive sector. The CSR Initiative at the Harvard Kennedy School, Cambridge, MA. https://www.hks.harvard.edu/sites/default/files/centers/mrcbg/programs/cri/ files/Costs\%20of\%20Conflict_Davis\%20\%20Franks.pdf

Franks, D.M., Davis, R., Bebbington, A.J., Alu, S.H., Kemp, D., and Scurrah, M. 2014. Conflict translates environmental and social risk into business costs. Proceedings of the National Academy of Sciences, vol. 111, no 21 pp. 7576-7581.

Fundacion Patagonia Tercer Milenio. 2008. Informe expeditivo - Provincia del Chubut. Trelew, Chubut, Argentina.

Garbarino, S. and Holland, J. 2009. Qualitative and quantitative methods in impact evaluation and measuring results. Governance and Social Development Resource Centre (GSDRC), University of Birmingham. https://gsdrc.org/ publications/quantitative-and-qualitative-methods-in-impact-evaluation-andmeasuring-results-3/

Geoservices SA. 2013. Environmental Impact Assessment - Tambomayo Gold Project. Nord Roissy-en-France, France.

Golder Associates. 2012. Updated preliminary economic assessment on the Angostura gold-silver underground project, Santander Department, Colombia, Lima. Bogotá, Colombia.

Gustavson Associates. 2012. NI 43-101 technical report on resources - Gramalote Project. Boulder, CO.

Gustavson Associates. 2014. NI 43101 preliminary economic assessment - Gramalote Project Northwest Colombia. Boulder, $\mathrm{CO}$.

HaRTMAN, H.L. 1987. Introductory Mining Engineering. Wiley.

HaRtman, H.L.1992. Elements of mining. SME Mining Engineering Handbook. Chapter 1.2. Society for Mining, Metallurgy \& Exploration, Littleton, CO.

HiLson, G. 2002. An overview of land use conflicts in mining communities. Land Use Policy, vol. 19. pp. 65-73.

International Council on Mining and Metals. 2012. Trends in the mining and metals industry. London

International Council on Mining and Metals. 2013. Approaches to understanding community development outcomes from mining. London

International Council on Mining and Metals. 2014. Learning from company-community conflict: Understanding practical dilemmas. London.

International Council on Mining and Metals. 2015. Research on company-community conflict. London.
International Finance Corporation. 2014. Water, mining and communities - Creating shared value through sustainable water management. Washington, DC.

International Institute for Environment and Development. 2002. Mining, Minerals and Sustainable Development Project. Chapter 9. IIED, London.

International Institute for Sustainable Development. 2007. Corporate social responsibility - An implementation guide for business. Geneva.

KIHLSTEDT, P. 1972. Waste water in metal mining industries. Pure and Applied Chemistry, vol. 29, no. 1. pp. 323-332.

Lycopodium Minerals Canada Ltd. 2014. Amended NI 43-101 technical reportfeasibility study of the Santa Rosa gold Project. https://redeaglemining.com/ projects/santa-rosa/technical-reports/3350/

MendozA, J.A.A. 2014. Proyecto de Mineria de Oro La Colosa, identificacion ambiental de la zona de explotacion y sus impactos. Pontificio Universidad Javeriana, Bogota. https://repository.javeriana.edu.co/bitstream/ handle/10554/13504/ArangoMendozaJulianAndres2014.pdf?sequence=1

MERIDIAN Gold. 2006. Annual Report. https://media.corporate-ir.net/media_files/ IROL/73/73063/AR_Meridian_Gold_2006.pdf

Moran, R. 2003. Esquel, Argentina: Predictions and promises of a flawed environmental impact assessment. https://earthworks.org/cms/assets/uploads/ archive/files/publications/PredictionsPromisesFINAL.pdf

Jenkins, H. and YaKovLova, N. 2006. Corporate social responsibility in the mining industry: Exploring trends in social and environmental disclosure. Journal of Cleaner Production, vol. 14, no. 3-4. pp. 271-284.

National Committee on Statistics. 2010. Population and housing census 2009. Bogota.

Newmont Mining CoRporation. 2015. 2014 annual report and form 10-k. https://www. newmont.com/wp-content/uploads/2019/05/861753_as-printed-AnnualReport_2014_v001_e83uds.pdf

NIETo, A. 2010. Key deposit indicators (KDI) and key mining method indicators (KMI) in underground mining method selection. Transactions of the Institution of Mining and Metallurgy, Section A: Mining Technology, vol. 328 pp. 381-396.

Nippon KoEı. 2009. Issyk-Kul sustainable development project, Kyrgyz Republic https://www.adb.org/sites/default/files/project-document/62284/41548-kgzdpta-v5-semp.pdf

OCMAL. 2015. Tia Maria: Agricultores del Valle del Tambo se oponen a la mineria. http://basedatos.conflictosmineros.net/ocmal_db/?page=conflicto\&id $=157$ [accessed 23 September 2015].

RoBERTSON, A. and SHAw, S. Mine closure. Infomine. http://w3.cenn.org/cenn projects/BfW_mining/Training/Managing\%20Effects\%20of\%20Major\%20 Mines/Reference\%20Materials/Risk\%20and\%20Deposit\%20Models/risk\%20 assessment $\% 20$ mine\%20closure.pdf

Santa Rosa de Osos Municipality. Development plan 2012-2015. Antioquia, Colombia.

Sims, J. 2014. Paracatu Project Brazil NI -43101 technical report. https://s2.q4cdn. com/496390694/files/doc_news/2014/paracatu-technica-report-mar-14.pdf

SMITH, D.C. and RichaRDS, J. 2015. Social license to operate: Hydraulic fracturing related challenges facing the oil and gas industry. Oil and Gas, Natural Resources, and Energy Journal, vol. 1, no. 2. https://digitalcommons.law. ou.edu/onej/vol1/iss $2 / 2 /$

Stevens, R. 2010. Mineral Exploration and Mining Essentials. British Columbia Institute of Technology.

Summers, J. 2000. Analysis and Management of Mining Risk. Proceedings of MassMin 2000, Brisbane, Old, 29 Oct.-2 Nov. 2000. Australasian Institute of Mining and Metallurgy, Melbourne. pp. 63-79.

Thomson, I. and Joyce, S.A. 2000. Mineral exploration and the challenge of community relations. Yukon Chamber of Mines, Whitehorse, Yukon Territory, Canada.

THomson, I. and Boutilier, R.G. 2011. Modelling and measuring the social license to operate: Fruits of a dialogue between theory and practice. https://www. socialicense.com/publications/Modelling and Measuring the SLO.pdf

THomson, I. and BoutiLIER, R.G. 2011. Social license to operate. SME Mining Engineering Handbook. Darling, P. (ed.). Society for Mining, Metallurgy and Exploration, Littleton, CO. pp. 1779-1796

United Nations. 2010. General Assembly. Human Rights Council, Fifteenth Session.15/9 Human rights and access to safe drinking water and sanitation. https://documents-dds-ny.un.org/doc/UNDOC/GEN/G10/166/33/PDF/ G1016633.pdf?OpenElement

WAGNER, L.S. 2010. Problemas Ambientales y Conflicto Social en Argentina.https:// ridaa.unq.edu.ar/bitstream/handle/20.500.11807/192/TD 2010 wagner_004 pdf? sequence $=1$ \&isAllowed $=\mathrm{y}$

World Bank and International Financial Corporation. 2002. Large mines and local communities. Washington, DC

Yamana GoLD. 2008. Annual report 2007. http://www.annualreports.com/ HostedData/AnnualReportArchive/y/TSX_AUY_2007.pdf 